Research Article

\title{
The Mediating Role of Employee Innovativeness on the Nexus between Internet Banking and Employee Performance: Evidence from the Republic of Congo
}

\author{
Jean Baptiste Bernard Pea-Assounga (iD) and Hongxing Yao \\ School of Finance and Economics, Jiangsu University, Zhenjiang, China \\ Correspondence should be addressed to Jean Baptiste Bernard Pea-Assounga; aspeajeanbaptiste@yahoo.fr
}

Received 15 December 2020; Accepted 26 April 2021; Published 8 May 2021

Academic Editor: Raffaele Carli

Copyright ( 2021 Jean Baptiste Bernard Pea-Assounga and Hongxing Yao. This is an open access article distributed under the Creative Commons Attribution License, which permits unrestricted use, distribution, and reproduction in any medium, provided the original work is properly cited.

\begin{abstract}
In recent years, banks have begun to realize the importance of Internet banking services and their connection with the banking sector. The main purpose of this article was to find the mediating role of employee innovativeness in the relationship between Internet banking and employee performance of certain banks in the Republic of Congo. A 350-sample size was considered, and a partial least square and structural model equation was used for data analysis. The research results suggested that Internet banking positively affects employee performance and employee innovativeness. They also confirmed that employee innovativeness partially mediates the relationship between Internet banking and employee performance. The theoretical model was built based on Diffusion of Innovation (DOI) Theory, Job Demands-Resources (JD-R) Model, Absorptive Capacity Theory (ACT), and Resource-Based View Theory. This work makes a more accurate contribution to the literature on Internet banking and employee performance. The study further provided recommendations and suggests directions for future studies.
\end{abstract}

\section{Introduction}

Innovation plays multiple roles in the growth and development of an organization to achieve maximum results. To manage an organization like a bank, it is a process of complexity that implicates the interactions of various factors [1-3]. With all these determinants, innovation technology and employee innovativeness are the main factors of employees' performance. Internet banking is regarded as an essential factor that influences both banks' and employees' performance because it improves the efficiencies of the employees, reduces banks' costs, lessens clients' wait-hours, and enhances performance $[3,4]$. Besides, financial innovation generates technology-based products with several advantages, such as high returns and low costs [1]. Similarly, the authors of [5] stated that innovation involves the creation and implementation of new processes, technology, the ways of delivery, and human capital, which results in significant improvements in production that make a firm more efficient than its rivals. Furthermore, innovation in the banking sector is widely accepted as an important factor that influences all of the employees, customers, and employee performance [6].

Although there are lots of empirical works about the cause-and-effect relationships in banking, most of them focused on one-on-one relationships between the factors and employed regression analysis or theoretical framework. For instance, the work of [7] have employed a theoretical analysis of the effect of technology on the nature of the job and came up with the view that innovation resulted in better employee's performance. They further concluded that Internet banking is an important determinant that significantly influences both individuals and organizations relating factors of bank-sector employees. Another theoretical study in [8] asserted that the effects of the Internet on well-being are mediated by a set of personal characteristics that are specific to each individual: psychological functioning, capabilities, and framing conditions. They added that interaction 
between human beings' activities in distinct domains of life and their characteristics explain why the use of the Internet has stronger positive effects for some individuals and social groups than others. Besides, the study in [4] has used pooled ordinary least square analysis to investigate the impact of e-banking on banks' performance in Bangladesh. The study concluded that e-banking had had a positive effect on the performance of banks, measured in terms of ROE, with a time lag of two years while a negative impact was found in the first year of Internet adoption. Owusu Kwateng et al. [9] investigated the effect of online banking on bank performance and employed data envelopment analysis. They argued that the implementation of Internet banking into traditional banking techniques leads to higher performance of banks.

There is little research on the nexus between Internet banking and employee's performance in developing countries. The current literature on innovation in the banking sector considers innovative banking and agents' growth, but it has neglected the impact of the employee innovativeness on employees' performance. Most of the studies of Internet banking services or innovation have been performed in economically developed nations [10-13]. Furthermore, the authors of [14] argued that developing countries might radically differ from developed countries when exploiting and exerting innovation. It is useful and necessary to carry out a study on the relationship between Internet banking and bank performance in developing countries. In our knowledge, this is the first paper investigating the relationship between Internet banking and performance in the Congolese context. Also, there seems to be no work done using employee innovativeness as a mediating variable. Therefore, this paper aims to bridge this gap by studying the effect of Internet banking on employee performance and the mediating variable of employee innovativeness in Congo. This research also aims to offer sufficient evidence to support Diffusion of Innovation (DOI) Theory, Absorptive Capacity Theory (ACT), and Resource-based View Theory (RBVT).

In this study, we outlined how Internet banking may influence employees' performance positively, and addressed this issue by analyzing data collected from the questionnaire of some selected banks in the Republic of Congo by applying the technical framework and structural equation modeling (SEM) through the help of Stata, SmartPLS, and SPSS software.

We have focused our study on the sample of some selected Congolese banks in which many aspects, such as management, organization, business, and production, are influenced by financial technology and innovation. Also, In the Republic of Congo, it is estimated that the ICT sector represents $4 \%$ of GDP [15]. With better infrastructure, its contribution is expected to be even greater, especially in the banking sector, where it already figures prominently. Internet banking in the Republic of Congo is greatly represented, and it has given a new trend to traditional financial services. In [16], survey showed that about 40 per cent of the population in Congo had utilized mobile services and mobile banking to carry out financial transactions (to transfer or borrow money and to pay bills). This highest share placed the country in the second position in CFA Franc and CEMAC areas behind Gabon, and fourth in sub-Saharan Africa (SSA), according to the Global Findex database [16]. IMF, 2014. Republic of Congo: Selected Issues, IMF Country Report No. 14/273. https://www.imf.org/ external/pubs/ft/scr/2014/cr14273.pdf. Driven by the rapid penetration of mobile phones, mobile banking ("Monnaie électronique") is developing as a product of financial innovation in the Republic of Congo, particularly in the CEMAC zone. Also, the actual number of Internet banking users with distinct banks has nearly tripled. The electronic monetary in 2013 base at these financial institutions, the volume of transactions peaked in the third-quarter amounted at XAF 8.5 billion, and an averaged of XAF 385 million [16]. According to the [15].Congo-Gabon: Toward Regional Digital Integration., n.d.), banks in the Republic of Congo are experiencing new technology, such as Internet banking and mobile banking, contributing to the country's economic growth. Besides, the electronic transactions (mobile banking) market has grown significantly in recent periods, improving financial access, and thus, it was a better environment to perform this study.

This paper contributes to the theory and practice within the fields of bank management and strategic innovation. Also, this study provides to bank management pieces of literature and practices in two ways. Firstly, this work assists in developing a better understanding of whether banking innovative services may influence management concepts like performance and employee innovativeness. Secondly, by revealing the mediating effect of employee innovativeness on the nexus between Internet banking and employees' performance, this research will enable the managers of banks and authorities of organizations to make their market grow by improving their innovation services. Finally, the outcomes of this article are of great importance in developing nations because it will evoke the attention of policymakers and managers of the bank to follow such policies to expand innovation and technology in the banking industry, which will ultimately convey long-term benefits to the entire financial system.

The next parts of this paper are structured as follows. Section 2 reviews the previous literature and hypothesis development. Section 3 deals with the methodology. Section 4 lays out our results. Section 5 presents the discussion of the outputs and conclusion. Section 6 carries out the study implications, and Section 7 deals with limitations and suggestions for further research.

\section{Literature Review and Hypothesis Development}

This section looks at the theoretical review and hypotheses development.

2.1. Theoretical Review of the Literature and the Conceptual Framework. The adoption of innovation in the Banking Sector has facilitated transactions and business worldwide. Internet banking structures, such as electronic checks payment system, Automatic Teller Machines (ATMs), credit visa, debit and master cards, mobile banking applications, 
etc., have transformed the world where clients may be able to purchase and sell goods and services, and also can make money transactions through the use of Internet $[7,14,17,18]$. Chai et al. [5] have confirmed that the introduction of Internet banking has increased efficiency, effectiveness, and productivity levels in the banking industry. It has enhanced employees' performance level in the world. Similarly, the authors of [19] believe that Internet banking variables have a positive impact on employee performance. Also, the work in [20] concluded that financial institutions that use the Internet banking application and other mobile banking applications do improve the efficiency of banking services, which enhances their financial performance. Campanella et al. [6] believe that Internet banking provides customers with opportunities to conduct business, regardless of their activity.

Also, customers can check their account balances, make transfers, learn about the bank's products and services, and find the schedule of the bank's nearest branch [14]. Innovation can be seen as a global trend in organizational learning. It succeeds by reducing the focus on specific innovation projects and focusing more on global changes that can create innovative capabilities and subsequently lead to organizational performance [21,22]. Researchers agree that innovation is the key to competitive advantage and strategic innovation [23-25]. In this sense, employees are vital to organizational innovation because they are responsible for modifying, interacting, and developing ideas [26], also known as Employee Innovative Behavior (EIB). Many employees view EIB as unusual and risky behavior efforts [27].

Similarly, to be innovative, organizations must manage and improve the internal environment that supports the characteristics of employees' creative behavior [28, 29]. Innovation is crucial as it reduces the perceived risks and negative responses of traditional cultural expressions [30]. An innovative internal environment will let employees know that their colleagues will respond positively, giving them more freedom to come up with new ideas. The pressure on financial industry innovation comes from increased competition and declining banking trends. Therefore, employees in the financial sector must develop new procedures and respond to new requirements to ensure organization competitiveness and effectiveness [31].

Ma et al. [12] noted that human capital creates innovation, and companies should pay attention to social capital development. Similarly, [32] argue that companies that have a competitive advantage over competitors need to be sustained through innovation. Wei et al. [33] believe that only those companies who understand the importance and value of innovation can promote innovation, increase their earnings, and attract customers through innovative methods and technologies. The studies in $[21,34]$ revealed a positive and significant relationship between innovation activities and performance. However, an investigation in [35] explained that due to the pressure to be competitive in the market, Firms always engage in investing in innovation and technology. Taking such a decision leads them to additional costs related to innovation, but the extra charges supported by the firms do not lead to technology and innovation outcomes. The findings of their study also indicated that more significant firms likely invest more and embark on technology and innovation activities, which decrease the outputs of innovation related to firms' size. They concluded that firms' behavior concerning investment in innovation is different in countries' groups. Similarly, Scott et al. [36] have seen that most innovation technology activities have extremely weak or negative outcome within the first few years of the adoption, which is in line with the idea that it takes years to fully implement technological and organizational changes and even longer for companies to start enjoying the benefits of adopting these innovations. Their findings propose that the appropriation of computerized advancement (e.g., SWIFT) mainly affects performance in the long run; these benefit impacts are more prominent for small banks than for enormous banks and show huge system consequences for execution.

In a related survey by [37] on the adoption of Internet and usage patterns in Mexico's rural population, the utilization of the Internet is correlated to a higher level of profitability. They further suggested that, it is required to improve conditions of access in providing satisfactory high-speed connectivity and infrastructure of Internet services; to reduce costs related to Internet connection by supporting healthy competition among service providers; and to impart digital literacy to individuals who may highlight the benefits and advantages provided by the usage of Internet. Technology answers can help a financial institution to innovate on methods such as digital dispersal of banking correspondence, direct banking, tolerating electronic documentation from clients [38], enhancing employee performance, and lowering inefficiencies [18]. Siddik et al. [4] researched the impact of innovative technology on the profitability of Bangladeshi banks. They concluded that technology adoption in banks had improved their performances as maturity is gained.

Similarly, Mohammad et al. [39] are of the view that innovation can facilitate organizations and their employees to be creative, improve communication, strengthen the image, reach or connect clients across the world, and finally enhance performance. Adopting the data for cross-country analysis from 2002 to 2016 and examining the bank's profitability determinants, the work in [40] show that the IT-based channel is positively and significantly associated with profitability. Ji et al. [41], by examining "the impact of information technology (IT) investment on enterprise financial performance in China," found out that financial gains of Information Technology (IT) implementations produce mixed outcomes. The outcomes also show that organizations putting resources into IT can altogether improve benefits with regard to both the usage and post-execution periods, improve the dissolvability just during the execution stage, improve the development capacity after execution time, and cannot diminish business costs in all periods.

Callaway et al. [42] has explained that Internet banking will likely carry out three essential profits that will improve banks' performance; expanding the market goal, expanding the breadth line of the product, and reducing the transaction cost. Internet banking may develop banks' market goals and the demanding determinant for the improvement of 
employee performance; however, it is notified that providing Internet banking will enable banks to cover a large geographic zone with a few mortar and brick branches.

Despite the advantages of innovation in the banking sector, some empirical studies mostly from developing nations indicated that innovation technology negatively affects overall bank performance [43, 44]. Le and Ngo [40] asserted that, regardless of the absence of an adequate wide variety of clients, higher costs in the infrastructure of Internet banking impact the benefit of banks negatively. Gutu [45] has confirmed that considerably higher promoting spending plan for web banking has not changed this circumstance. It is demonstrated that those clients in these nations, despite everything, request conventional branch-based financial services. Along these lines, the gainfulness of electronic financial services is antagonistically influenced because of not giving the regular cost decrease [43]. Another study by Beck et al. [46] revealed that various measures of financial innovation, which encompass both broad concepts and specific innovations, are related with faster bank growth but also with greater bank fragility and poor performance during the recent crisis. They reasoned that monetary advancement influences decidedly financial development, and it is in addition connected with higher development in nations and ventures with better development openings.

The introduction of Internet banking has reduced the severe traffic of customers in the banking halls in the last three decades. The reduced numbers have made the lives of customers very convenient, and they can quickly access their monies at any point in time within the day. The work of [17] pointed out the fact that the use of innovation such as applications, Automated Teller Machine services (ATMs) have contributed positively to the banks' performance and had a significant effect on other banks' factors as well.

Employee innovativeness in an organization depends on many factors, but the most paramount one is motivation and workplace atmosphere [47]. Motivation enhances the employee's abilities to be innovative and contribute to overall organization innovation and technology success [48]. Motivated employees tend to be creative and perform excellently on the job; this is because job motivation plays a critical role in the employee's innovativeness. This results in employee performance and then enhances firm performance as a whole [12]. Innovative employees respond to individual motivation for innovation and technology through creative actions and ideas [48].

However, less creative employees will feel their work is exposed by the higher adequate process established by coworkers [49]. Uncertainty emerges as a consequence of innovative activities that jeopardize status and, in general, lead to unemployment. As a result, employees may have diverse mindsets toward innovations [50]. Creative employees may be more attracted to the employment market, cannot worry about work safety due to the attractiveness of jobs, and consider it easy to find new posts when necessary. In contrast, noninnovative employees see innovativeness as a risk [50], and innovation schemes proposed by coworkers reduce their security and job opportunity [51]. Although literature under employee innovativeness and employee performance is very scanty, the few available have proven that there is a significant relationship between them. A study in [52] looked at the effect of networking on competitiveness through employee innovativeness, organizational learning, and innovation process in 110 Indian firms. The outcome of the study suggested that there is a strong relationship between networking and employee innovativeness. They further explained that there is a positive relationship between employee innovativeness and competitiveness, which leads to organizational performance. Rajapathirana and Hui [22] have examined the nexus between innovation types, innovation capability, and firm performance using insurance companies of Sri Lanka as a case study. They picked 379 high-ranking managers as samples of the companies, as mentioned above. They analyzed the data employing Structural equation modeling. The outcome shows that organizations with higher capacities of innovation have affected emphatically and firmly. Along these lines, it helps develop innovation ability, which is the core to insurance agencies to characterize fruitful change. The insurance sector required to turn from a generally risk unwilling society to one that energizes experimentation while moderating the money-related risk. To accomplish this, safety net providers should take advantage of new wellsprings of innovation, getting to new thoughts from clients, employees, financial specialists, and partners, which, thus, will require dynamic authority at the highest point of the organization. Another empirical study in [29] investigated "The Relationship Between an Innovation Orientation and Competitive Strategy." The author collected primary data from 326 respondents across selected organizations in Canada. The study uses simple random sampling and employed cluster analysis.

The result shows clear evidence that innovation orientation is significantly related to competitive strategies. The author further asserted that innovativeness in a company is a broad concept and is defined as the ability to innovate or introduce a specific novel idea, service, or product through the introduction of systems and processes, which can foster improved company performance. Besides, the authors of [53] characterized employee innovativeness as the degree of employee's capacity in which employee actively generates and promotes novel ideas according to participation, work quality, the limit of execution, and individual components. Subsequently, banks are resolved to build information and upgrade the range of abilities of their workers since their innovative ideas lead to employee job performance, and it is vital in their general productivity $[24,54-56]$.

\subsection{Theories Related to Study Framework and Hypotheses.} Internet banking has gained considerable interest in technology adoption studies in recent years. Information System (IS) has been used by the banking sector not just for internal business operations but also to provide its clients with key services [57]. The greatest known theoretical approaches, which have attempted to explore the link between attitude, consumers' beliefs, and intention, are as follows: Social Cognitive Theory (SCT) developed by [58]; the Motivational Model (MM), investigated in [59]; Diffusion of Innovation 
(DOI) Theory, examined in [60]; Theory of Planned Behavior (TPB), the hybrid model, which incorporates TAM and TPB (C-TAMTPB)' constructs, developed in [61]; Model of PC Utilization (MPCU), developed in [62]; and Resource-Based View Theory (RBVT) introduced in [63]. As the aim of this research is to associate the adoption of Internet banking with its usage concerns in the innovation technology aspect, for this reason, scholars have assumed to undertake the Resource-Based View Theory (RBVT), Absorptive Capacity Theory (ACT), and Diffusion of Innovation (DOI) Theory.

2.2.1. Resource-Based View Theory (RBVT). Barney [63] introduced the Resource-Based View (RBV) to resolve the shortcomings of external and internal environment of competitive edge, attempting to provide a connection among heterogeneous resources regulated by an organization, resource mobility within a specific industry, and the strategies or competitive advantage gained by a company. The resources of a business are utilized to formulate strategies to increase the organization's overall productivity and performance, and these resources can be very diverse [64]. Barney [63] divides these assets into three groups:

(i) "Physical capital resources" comprise organizations' physical resources such as equipment and plant, location, technology, and raw materials access.

(ii) "Human capital resources" are referred to as the judgment, training, intellect, experience, and insight of employees and managers within a company.

(iii) "Organization capital resources" refer to the organization's formal structure, preparing, managing, and organizing processes, informal and formal reporting and "planning systems," and informal relationships between teams within the organization, and external companies in the competitive marketplace.

The Resource-Based View (RBV) of the company is a competitive advantage technique that arose in the 1980s and 1990s as a result of hard work of scholars and entrepreneurs [65-67]. The theory's fundamental concept is that instead of relying on the dynamic business environment to find a market niche or gain an advantage over rivals and risks, the company should focus on the resources and opportunities that it already has $[64,68,69]$.

According to RBVT, it is much easier to take advantage of potential opportunities by using existing tools and competencies rather than trying to develop traits, new skills, or functions for every opportunity [64]. The RBV model's key emphasis is on these assets, with proponents claiming that they must be prioritized in the development of organization strategies. However, the contingency theory states that most resources within a given company are homogeneous due to their high mobility, the Resource-Based View Theory (RBVT) begins from two possible assumptions: "resource heterogeneity" and "resource mobility" $[63,64,70,71]$. Agreeing to RBVT, companies can handle several resource bundles, and resource bundles are difficult to transfer between businesses, raising heterogeneity in enterprise resources [72]. The RBVT implies that the company becomes superior compared to other organizations if the resource is rare, valuable, nonsubstitutable, and imperfectly imitable, through the abovementioned alternative assumptions $[63,73]$. In short, RBVT determines that the company's ability to establish a competitive advantage is connected to the strength of its corporate capital (resources), while the Market-Based View (MBV) believes that the company's competitive advantage is determined by the company's market position [70, 71, 72, 74]

As a result, supporters of the RBVT argue that the paradigm is changing away from a company's market position and toward its strategic resources [63, 67, 74-76].

Finally, Resource-Based View Theory (RBVT) explained that ownership of capitals (resources) is precious, hard to imitate, infrequent, and are not replaceable $[64,68,71]$. This implies that companies' assets are given the significant role of helping organizations in accomplishing higher performance, and gaining competitive advantage and sustainability [69].

2.2.2. Absorptive Capacity Theory (ACT). Cohen et al. [77-79] described absorptive capacity as a company's ability to "recognize the importance of new, external knowledge, assimilate it, and apply it to commercial ends." Consequently, absorptive ability is the process that helps an entity to absorb and use external information. Domain-specific knowledge acts as the raw material for individuals' innovative ideas $[80,81]$, and it is organized into domain-specific knowledge structures or schemas [82].

While the authors of [78] suggested absorptive ability as a mechanism for absorbing various types of information, they later narrowed their attention to technical knowledge ("solution knowledge"). They suggested absorptive capacity as the "second face of R\&D" [77], which is the notion that prior expertise derived from in-house $R \& D$ activities is the primary feedstock for companies' absorptive capacity. Following in this tradition, recent researches described absorptive capacity as the ability to absorb technological information and measured it in terms of patents, scientists, and R\&D spending [83]. Innovations relying on emerging technology are clearly relevant and play a major role in influencing the evolution of companies and industries. Even though studies have also shown that technology pushing and requirement pull can be equally effective sources of innovation success $[84,85]$, absorptive capability research has primarily focused on technology.

Researchers have recently realized that the type of absorptive ability required is determined by the essence of the information to be absorbed, and therefore have requested for more cautious distinction types of knowledge $[83,86]$. Fiske and Taylor [83] assert that absorptive capacity research should be more precise in terms of the form of information to be absorbed, and that applying absorptive capacity outside of the technology field is "entirely consistent with [78]'s idea."

In comparison to the comprehensive studies on how companies absorb technical information [78, 87], the 
capacity of companies to absorb necessary knowledge for innovation receives little attention in the management discipline. Although the authors of $[83,86]$ stress the importance of need absorption aimed at innovation, little scientific investigations have followed up on this theory. The ability of a company to absorb information from clients and rivals is based on prior business awareness, according to [88].

Individual workers have the potential to acquire information from outside the company. Individual workers are expected to seek out and learn across external information sources $[89,90]$. "All learning is taking place within individual human heads," writes Simon [91]. Cohen and Levinthal incorporate this idea into their concept of absorptive capacity, stating that a company's absorptive capacity "will be determined by the absorptive capacities of its individual members" [78]. Individual absorptive capacity therefore serves as the base for organization absorptive capability, which can be augmented by organizational processes like social interaction $[92,93]$.

Nevertheless, many studies have concentrated on absorptive ability at the company level $[83,86]$, or on the partnership level [92], or on the company units level [94], ignoring the person level. In contradiction of this context, many researchers have stated that "more individual-level foundation for AC [absorptive capacity]" must be built $[83,86]$. Researchers have started to increase our comprehending concerning absorptive capability from individuallevel aspect in replying to these requests $[88,95]$. "Individual absorptive capability" has been linked to cognition, knowledge, and external networks diversities [88], and also has been linked to positive outputs including "task performance" [96], knowledge generation [92], and "innovativeness" $[95,97]$.

2.2.3. Diffusion of Innovation (DOI) Theory. Research by Ryan and Gross [98] contributed to the first formulation of the diffusion paradigm. In his book DOI, published in 1962, Rogers [60] suggested four components of diffusion: communication channel, innovation, social system, and time. Diffusion occurs over time among members of a social system via a variety of communications channels. Awareness, persuasion, choice, execution, and affirmation are the five phases of the adoption process suggested in [99]. Awareness is described as when a person is introduced to the presence of a technology-innovation and develops a comprehension of how it operates. As a result, persuasion is characterized as the mechanism by which a person develops a positive attitude toward a technology-innovation. Individuals at this point, according to [99], become psychologically active and seek knowledge about the technology through their peers. The decision stage of the adoption process is the third stage. It was described as a situation in which a person involves in activities that would assist to the acceptance or rejection of a technology-innovation. The stage four of the adoption process is "implementation," which is when a person starts to use an innovation. Finally, the fifth stage is validation, in which a person requires confirmation for a technology-innovation decision that has already been made but can be reversed if contradictory communications about it are obtained.

Diffusion, according to [99], is a process through which an innovation is transmitted via specific channels between social system members, whilst the innovation is an "idea or practice" that is viewed as novel by a person. Yi et al. [100] describe individual innovativeness as "the ability of an individual to try out any new IT, which plays a significant role in deciding the outcomes of user acceptance of technology." Individual innovativeness, according to [101], is a significant factor in deciding the outcomes of technology-innovation adoption. Innovation has previously been shown to have a substantial effect on users' ability to implement new technologies [100]. Innovativeness is found to have a substantial effect on compatibility, effort expectancy, and performance expectancy, as well as to having a direct effect on users' behavior to implement technology-innovation $[3,102]$.

2.3. The Conceptual Framework of the Study. Figure 1 designates the current study conceptual framework explaining that employee performance would be influenced based on the measurements as follows: Innovation technology characteristics measurement represented in this study by Internet banking (IB), and the personality measurement described by employee innovativeness (EI).

2.4. Development of Research Hypotheses. The world is currently living in a period when the marginal benefits of technology, without any considerations, still outweigh the minimal costs associated with it. Hu and Xie [1] have acknowledged the importance of Internet banking to increasing efficiency, effectiveness, and profitability levels in the banking industry.

Traditionally, organizational performance has been determined using economic metrics such as benefit, market share, growth rate, and earnings [103]. In accessing efficiency, however, nonfinancial metrics traditionally established in relation to human resources' (HR) outputs, such as absenteeism, turnover, work satisfaction, quality, and productivities, must also be taken into account [104]. Organizations should give great importance to employee performance in orderliness to achieve a competitive advantage and attain success $[105,106]$.

Employee performance is all about how workers achieve organization goals and relate their behavioral activities to organizational norms [106], and how employees execute mutually agreed tasks in a timely, productive, and successful manner, as planned out by the supervisor [107].

It was obtained that innovation affects the efficiency of workers [108]. Innovation will ultimately boost productivity via employee generating ideas for novel services and products [108], better administrative processes, enhance efficiencies and successful job management [109], improve organization suitability [110], and increase overall organizational performance and efficiency [108]. Innovation would also improve the quality, quantity, and timeliness of 


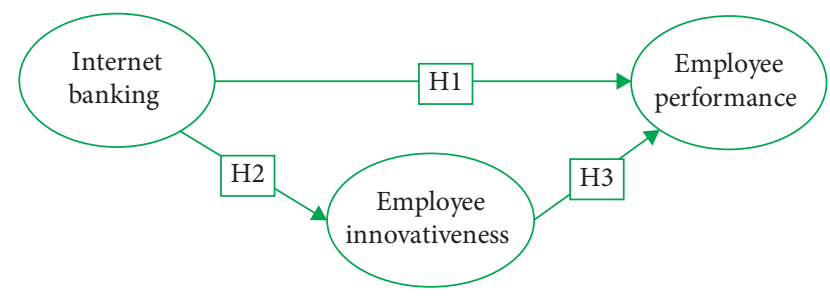

Figure 1: Conceptual model and hypotheses of the study.

production, involvement in the workplace, and efficiency to complete the task [109].

A study in [111] has found that different types of innovations, namely, organizational, technological, process, and product, all have a positive effect on employee performance. The authors concluded that there should be no decrease in innovation activities at the utility business. They also recommended that the organization should consider itself fortunate to have workers who are excited about innovation as it can contribute to increase in productivity.

Also, research on the relationship between Internet banking and banks' performance has found a significantly positive correlation between the variables [5, 19, 20, 32, 40]. However, this relationship may not be apparent in the shortrun because of the high initial costs often associated with capital investments, and the influence of environmental and social factors on the acceptance of change in organizations. Hypothesis 1, therefore, investigates this relationship as it relates to the Republic of Congo.

$\mathrm{H} 1$ : internet banking positively affects employee performance.

The degree to which a computer program assists users in creating and testing new ideas is referred to as task innovation. The effect of information technology on task creativity is becoming more commonly known [112]. Torkzadeh and Doll [113] published a study of the postindustrial literature on the effect of technology on individual workers' work and suggested four dimensions, namely, job creativity, task efficiency, customer satisfaction, and management control. Task creativity was probably the most vital of these, as it is needed to increase efficiency, customer satisfaction, and control [108]. We believe that via iterative learning cycles, new ideas will be produced and tested. Many creative ideas may be produced during such experiential periods, and while not all will be implemented, most may provide workable solutions. The secret to job productivity is an innovative approach, and as more innovative solutions are integrated into engineering practice, productivity increases. Therefore, the more creative a job is, the more efficient it is $[92,96]$.

Obeng and Mkhize [18] have investigated the responses of employees and clients to technology innovation in the banking industry. The study found a positive impact of technology on employees' performance, and asserts that factors such as employees' training and motivation could have a toll on the relationship. This finding emphasizes the role of the organization and management in the success of Internet banking. Melián-González et al. [114] expressed that IT partakes vigorously in the undertaking productivity of office laborers, who depend on IT to complete their activity. They concluded that IT legitimately collaborates with different factors that decide workers' performance. A study in [115] asserted that as an innovative atmosphere, it could be necessary to establish knowledge and information flows freely. This means that innovation technology (considered here by IB) leads to employee innovativeness since it assists them to work creatively and efficiently.

Similarly, the work of [116] demonstrated that transformational leaders cultivate an innovation atmosphere that stimulates worker inventiveness and creative self-efficacy, and directs the linkage innovation atmosphere and employee innovativeness. They concluded that workers with great creative self-effectiveness resort to innovative behavior once they get a secure innovation atmosphere. Based on the work of [117], confidence in innovation helps companies break through the various thresholds set by noninnovative and innovative employees. Therefore, an atmosphere of trust in innovative work encourages employees to carry out novel ideas and understand that this may not lead to work-associated job discords [118].

An investigation in [119] entitled "Education and core skills in the performance with mediating role of employee innovation," revealed that employee innovation has a statistically significant and positive effect on employee performance. Other results of their study showed that employee education and employee core skills exert direct effects and indirect effects via employee innovation on employee performance. In addition, the authors of [96] have found that the use of IT positively influences task innovation, which in turn affects task productivity significantly. In the economic framework of this work, the positive impact of confidence in innovation has been attributed to numerous innovation processes that often negatively impact the workplace. Based on the above discussions, we hypothesized that:

$\mathrm{H} 2$ : internet banking affects employee innovativeness positively.

Investigating the effect of networking on competitiveness through employee innovativeness, organizational learning, and innovation process in 110 Indian firms, [52] suggested that there is a strong relationship between networking and employee innovativeness. They further explained that there is a positive relationship between employee innovativeness and competitiveness, which in turn leads to organization performance. A study by [120] suggested that participation in innovation is a common factor in explaining the relationship between political competition and employees' performances. Given the importance of innovation for a firm's growth and success, innovators who succeed in each step are likely to be perceived as great performers. Therefore, hypothetical models of innovations take performances as the eventual result of employees' innovations [121]. Experimental work has also shown that there is a positive correlation between employees' creativity, supervisors, and employees' performances, which substantially leads to overall performance [122]. Conceiving innovation-driven techniques 
that encourage information disclosure and improve the ranges of abilities of workers is imperative because the accomplishment of banking foundations and the acknowledgment of their targets rely to a great extent upon human assets. Minh et al. [56] asserted that employees could help increase company performance via their capacity to innovate and generate novel thoughts and utilize these as constructing blocks for better and new services, products, and work procedures. From the above point of views, we came out with the hypothesis that;

H3: employee innovativeness positively affects employee performance.

\subsection{Mediation Role of EI on the Nexus between IB and EP.} Employee innovativeness refers to the tendency of employees to innovate, generate, and create. It can be understood as a complex behavior, including producing, promoting, and implementing ideas to achieve organizational goals innovatively [23, 24, 123].

The mediating role of employee innovativeness ideas is relying on and adopted from the Job Demands-Resources (JD-R) model, Diffusion of Innovation Theory, and Resource-Based View Theory. The model partially posits that great job resources will lead to increased motivation, resulting in higher productivity [124]. Resource-Based Theory explained that ownership of capitals (resources) is precious, hard to imitate, infrequent, and are not replaceable. This implies that companies' assets are given the significant role of helping organizations in accomplishing higher performance and gaining competitive advantage $[68,69]$. Based on these models, Internet banking is an essential factor leading to employee innovativeness and better productivity, thus gaining positive outputs such as higher performance. Apart from theoretical supports, there are also some empirical views. For instance, the authors of [7] highlight that Internet banking affects the organization and banks' employees by boosting employee satisfaction, reducing cost and clients wait-hours, increasing employee productivity, and finally enhancing bank performance.

Moreover, the authors of [125] argued that innovation in the banking sector is widely accepted as an essential factor that influences employees and performance, which leads to prosperity of high value-added and competitiveness. Also, the authors of $[39,126]$ asserted that the Internet is an essential element that can increase employee productivity and enhance performance.

Doran and Ryan [26] acknowledged that creativity is widely considered as an important element of innovation; thus, organizations are highly relying on the innovation and creativity of their employees. Moreover, the work in [127] reasoned that banks produced their yield at the branch-level during a mix of administrations from work, and from IT investment, under a steady come back to scale innovative work.

From the above theoretical supports, empirical views, and since Internet banking services may be a prerequisite for employee innovation and employee performance, employee innovation can help to evaluate employee performance, so we assume that employee innovativeness will mediate the relationship between Internet banking and employee performance. According to this assumption, the hypothesis below will be tested:

H4: employee innovativeness mediates the relationship between Internet banking and employee performance.

\section{Methodology}

3.1. Data. This article uses a research methodology that focuses on using quantitative techniques to collect and analyze data. A structured questionnaire was adopted to measure the quantitative variables. The purpose of this study was to examine the effect of Internet banking with employee innovativeness mediation on employee performance. The data were gathered from the distinctive work units of some selected banks currently operational in Brazzaville, the Republic of Congo, where most of the banks' branches are located. The respondents of the investigation were randomly chosen from the ranks of senior manager, associate, and branch manager who were well-informed about the important constructs of the research. Respondents in this investigation replied to the questions deliberately and were educated regarding the point of the study. The study instruments were translated to French and afterward retranslated into English to guarantee accurate interpretation and that the planned implications of the items have been transmitted. Adjustments were made as fundamental. Not all banks consented to take an interest in the current research, so the survey was distributed to the branches of the banks that agreed (10 banks out of 13), which represents the majority of the population of the study. Four hundred respondents were targeted, but only three hundred and fifty responses were received and considered after initial data cleaning. The data were collected from October 2019 to December 2019. The data sample size was chosen depending on the rule recommended in $[128,129]$, e.g., to determine the ratio $(r)$ of indicators to latent variables and calculating the sample-size lower bound. Applying this standard, the base number of tests required should verify this function $n \geq 50 r^{2}-450 r+1100$. The $r$ can be determined as $r=p / k$, with $p$, the number of indicators and $k$, the number of latent variables. After computing, $p=16 ; k=3 ; r=5.33$ and $400 \geq 50(5.33)^{2}-450(5.33)+1100$. We finally find that $400>122$, and according to previous investigations employing questionnaires as main the source of study data, the sample size above 200 is referred to as good for an accurate research $[130,131]$. The last number of valid surveys gathered and investigated was a total of three hundred and fifty samples out of four hundred respondents initially targeted, which represents $87.5 \%$ of responses used in this work. The study also adopted a Likert scale, varying from $1=$ strongly disagree to $5=$ strongly agree and considered relevant questions from other researchers who used identical researches. The questionnaire has been divided into three different folds. The first fold contains questions on demographics; the second considered the measurement of the construct, while the third fold dealt with dependent 
variables. The study items questionnaires show up in the appendix (Table 1).

Measurements used in this paper were adopted from previous researches and adapted for this current work. The items measurement of Internet banking were taken from $[132,133]$, the items for employee innovativeness was adopted from $[3,24]$, while the items for employee performance was taken from $[130,132]$.

Data collected from the respondents were scrutinized through the usage of SPSS version 26 and Stata version 14. SPSS was considered for demographic analysis and testing of the hypothesis was done using Stata for the structural equation model. Principal Component Analysis (PCA) Confirmatory and Exploratory Factor Analysis were adopted for assessing and purifying the unidimensional items on the scale and again assessing the validity of discriminants among constructs.

\subsection{Rationale of the Use of a System of Regression Equation} Models in Path Analysis. Along with its ability to handle nonordinary data disseminations, System of Regression Equations in Path analysis has recently become one of the most well-known multivariate investigation techniques in the social sciences. In addition, System of Regression Equations describe path coefficients in terms of regression coefficients and is a full information method [129]. Particularly, the test of hypotheses is well defined and can convincingly reject alternative hypotheses. Also, it allows for plotted residuals inspected for data issues such as heteroskedacity, autocorrelation, outliers, nonnormality, etc. [129]. In light of that, utilizing the System of Regression Equations Models in Path Analysis can be increasingly reasonable to accomplish the investigation goals.

From the conceptual framework in Figure 1, we came up with the system of equations as follows:

$$
\left\{\begin{array}{l}
\mathrm{EP}=\alpha_{0}+B_{0} \mathrm{IB}+\varepsilon_{1}, \\
\mathrm{EI}=\alpha_{1}+B_{1} \mathrm{IB}+\varepsilon_{2}, \\
\mathrm{EP}=\alpha_{2}+B_{2} \mathrm{EI}+\varepsilon_{3}, \\
\mathrm{EP}=\alpha_{3}+B_{3} \mathrm{IB}+B_{4} \mathrm{EI}+\varepsilon_{4},
\end{array}\right.
$$

with $B_{0}, B_{1}, B_{2}, B_{3}$, and $B_{4} \neq 0$.

3.3. Confirmatory Factor Analysis (CFA). To ensure data reliability, discriminant and convergent validity tests were employed, using statistical package for social sciences (SPSS V.23).

Principal Component Analysis (PCA) with varimax rotation (Varimax with Kaiser Normalization) has been adopted to recognize factors producing eigenvalues higher than 1 . The PCA conducted in this study has included exploratory factor analysis (EFA) and confirmatory factor analysis (CFA). Confirmatory factor analysis is a multivariate statistical procedure that is used to test how well the measured variables represent the number of constructs. The confirmatory factor analysis (CFA) is also considered again because we are testing
TABle 1: Questionnaire.

Internet Banking (IB)

IB1-You feel confident while using e-banking method to access money

IB2-Internet banking enables me to complete a transaction quickly

IB3-Online banking enhances your effectiveness in doing banking transactions

IB4-You find online banking useful

IB5-Online banking saves your time

IB6-Overall, online banking is easy to use

Employee innovativeness (EI)

EI1-I like to experiment with new information technologies

EI2-Innovation is essential for doing my job effectively

EI3-I am creative at work

EI4-If I heard about a new information technology, I would look for ways to experiment with it

EI5-I know the process for giving input or new ideas

Employee performance (EP)

EP1-I think that using Internet banking would improve my performance

EP2-I think that using Internet banking would increase my productivity

EP3-I think that using Internet banking would enable me to conduct tasks more quickly

EP4-Internet banking is useful to carry out my tasks

EP5-Using internet banking increases the quality of my banking services output at minimal efforts.

The highlighted questions were later removed due to low loadings (see Figure 2).

the common method variance in our study. In the data reduction process, the variables with factor loading of 0.500 or more are normally required to be considered for analysis. Initially, 16 items were keyed in but 3 of them (EI5, EP4, and EP5) were later removed due to outlier or low loadings leaving 13 items for three factors (see Figure 2).

The performed exploratory factor analysis (EFA) of study items, indicated three-factor solutions, accounted for $72.5 \%$ of the total variance in the study factors, with $\mathrm{KMO}=0.830$; Bartlett's sig. $=0.000$ and the Scree plot direction has changed from a factor of 4 . Bartlett's test of Sphericity was adopted for the measurement of construct validity while the Kaiser-Meyer-Olkin (KMO) was employed for the measurement of sampling adequacy of individual variables. The Bartlett's test of Sphericity from Table 2 shows that the correlation between the variables is 2882.757, which is sufficient and significant $(P<0.000)$. Scales of each factor have an excellent correlation with each other; this confirmed the scale convergent validity [129].

The outcomes of CFA prove that 13 items' loading values are larger than 0.70 ; also, these outputs indicate that every item is highly loaded in its underlying construct (see Table 2). This demonstrates that the indicators (items) used are reliable and sufficient $[134,135]$.

3.4. Reliability and Validity of Scales. The values of composite reliability and Cronbach's Alpha were evaluated to study the reliability of the constructs. 


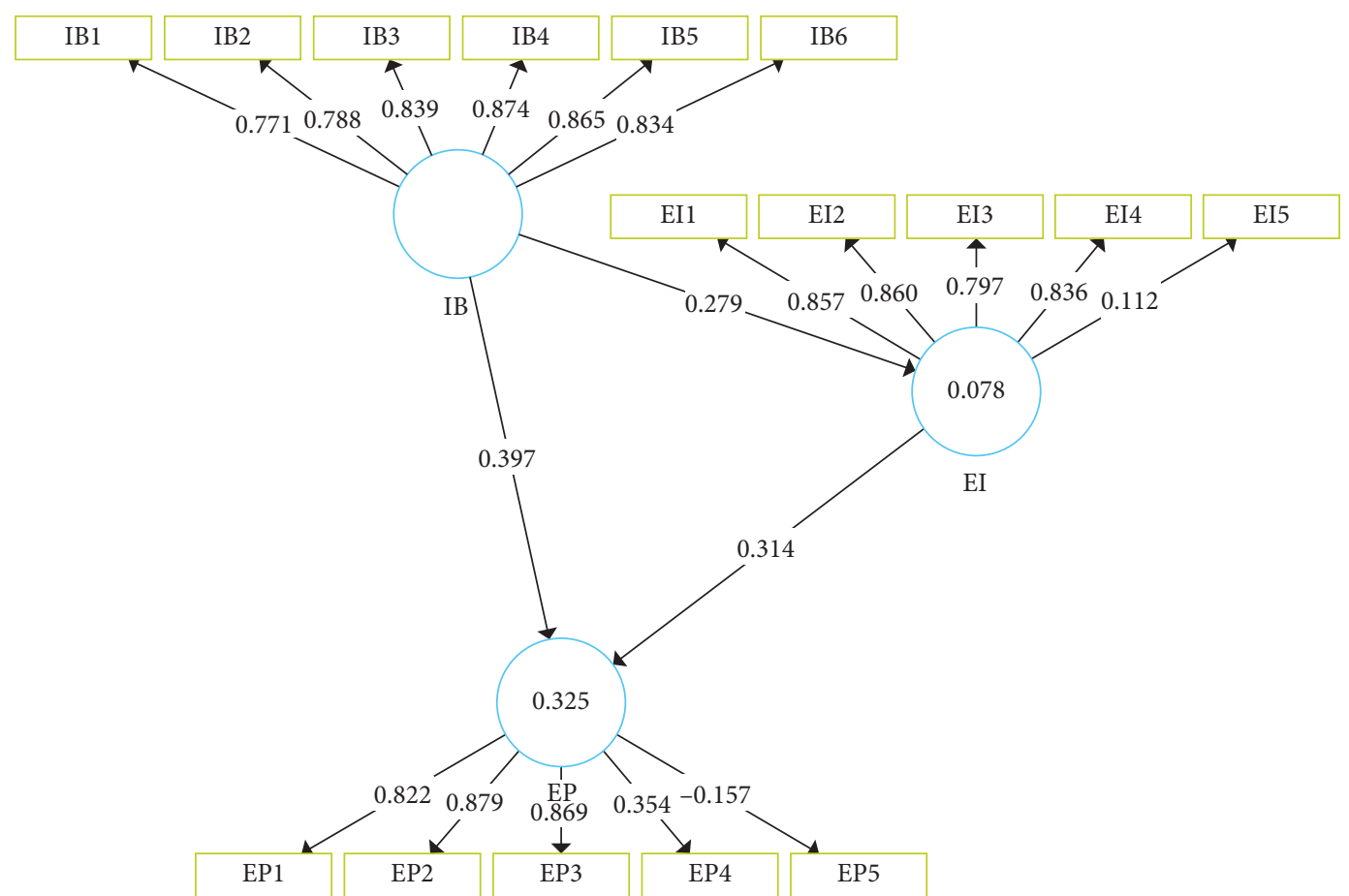

Figure 2: EFA, first test. (a) Normal Q-Q plot of EP. (b) Normal Q-Q plot of EI. (c) Normal Q-Q plot of IB.

The values of Cronbach's Alpha (CA), composite reliability (CR), and average variance extracted (AVE) can be obtained by the following formulas:

Cronbach's alpha is a measure used to assess the reliability or internal consistency of a set of scale or test items. Cronbach's alpha (CA) is defined as

$$
\mathrm{CA}=\frac{k}{k-1}\left(1-\frac{\sum_{i=1}^{k} \sigma_{Y_{i}}^{2}}{\sigma_{X}^{2}}\right),
$$

where $\sigma_{X}^{2}$ is the variance of the observed total items' scores and $\sigma_{Y_{i}}^{2}$ the variance of component for the current sample of persons.

Composite reliability (CR) and average variance extracted (AVE) are defined as

$$
\begin{aligned}
\mathrm{CR} & =\frac{\left(\sum \lambda\right)^{2}}{\left(\sum \lambda\right)^{2}+\sum\left(1-\lambda^{2}\right)}, \\
\mathrm{AVE} & =\frac{\sum \lambda^{2}}{n},
\end{aligned}
$$

where $\lambda$ represents the factor loading and $n$ the number of items (number of factor loadings for each latent variable you wish to compute AVE and CR).

Results indicated that the Cronbach's Alpha (CA) vary from 0.849 to 0.907 , which is above the acceptable range of 0.70 . Besides, composite reliability $(\mathrm{CR})$ varying from 0.870 to 0.917 is likewise greater than 0.70 and implies that the variables are highly reliable [129].

To check convergency validity, the values of the average variance extracted (AVEs) have been assessed. The outputs show that AVEs' esteems for this investigation run from 0.650 to 0.698 , which is satisfactory and higher than the essential limit degree of 0.5 . All validity and reliability outcomes are shown in Table 3.

We have run the descriptive analysis of the variables that constituted Means (M), standard deviation (Std. Deviation), and constructs' correlations. The findings of the investigation mentioned above showed a significant and positive correlation between the study's constructs, and the values ranged from 0.263 to 0.454 . The results in Table 4 indicated no value of correlation surpasses the threshold of 0.9 , so it tends to be affirmed that there is no common methods bias between the study variables [136].

3.5. Common Methods Bias Test. It is vital to perform a common method of bias test since both exogenous and endogenous variables were gathered together utilizing the same questionnaires [136]. For the constructs of the study, Harman's single factor test has been employed. The result indicated that the only factor merged explains about $42 \%$ in the total variance of the model, which shows a lesser value than the critical level of $50 \%$, so it has been affirmed that there is the absence of common methods bias in the constructs [136].

Based on the preliminary tests, all measures fulfill the validity for different constructs of the study. The assessment of convergent validity, and factors reliability, provide satisfactory outcomes, demonstrating that all constructs are highly reliable and can be utilized to examine the theoretical models.

Before inspecting the connections among the variables in our study model, as one of the most significant standards in which we would assess the legitimacy of the outcomes, the information was analyzed to decide whether it had ordinary 
TABLE 2: Results of factor analysis.

\begin{tabular}{lccc}
\hline & \multicolumn{3}{c}{ Component } \\
& IB & $2(\mathrm{EI})$ & $3(\mathrm{EP})$ \\
\hline IB1 & $\mathbf{0 . 7 6 0}$ & 0.001 & 0.176 \\
IB2 & $\mathbf{0 . 7 9 0}$ & 0.157 & 0.076 \\
IB3 & $\mathbf{0 . 8 2 2}$ & 0.153 & 0.104 \\
IB4 & $\mathbf{0 . 8 1 3}$ & 0.115 & 0.267 \\
IB5 & $\mathbf{0 . 8 1 7}$ & 0.097 & 0.243 \\
IB6 & $\mathbf{0 . 8 3 3}$ & 0.050 & 0.137 \\
EI1 & 0.156 & $\mathbf{0 . 7 7 1}$ & 0.281 \\
EI2 & 0.078 & $\mathbf{0 . 8 6 0}$ & 0.131 \\
EI3 & 0.030 & $\mathbf{0 . 8 3 9}$ & 0.089 \\
EI4 & 0.151 & $\mathbf{0 . 8 6 9}$ & 0.018 \\
EP1 & 0.140 & 0.090 & $\mathbf{0 . 8 5 7}$ \\
EP2 & 0.287 & 0.167 & $\mathbf{0 . 8 0 9}$ \\
EP3 & 0.238 & 0.188 & $\mathbf{0 . 8 2 8}$ \\
Eigenvalues & 5.499 & 2.445 & 1.481 \\
Cumulative variance explained (\%) & 42.301 & 61.110 & 72.502 \\
\hline
\end{tabular}

Kaiser-Meyer-Olkin measure of sampling adequacy $=0.830$; Bartlett's test of sphericity $=2882.757 ; p<0.000$. Bold values are loadings for items, which are above the threshold value of 0.5 .

dissemination. For this reason, the Kolmogorov-Smirnov and Shapiro-Wilk tests were assessed, and it was seen that all values are between the limit values of lower -2 and upper +2 and the lower -4 and upper +4 regarding, respectively, Skewness and Kurtosis [137, 138]. The results of Kolmogorov-Smirnov and Shapiro-Wilk tests both showed significance, which implies that the null hypothesis of normality should be rejected (see Table 5). However, many researchers have argued that these two tests (Kolmogorov-Smirnov and Shapiro-Wilk) are sometimes weak and unreliable when the sample size is larger, e.g., greater than 300 [137-139]. These authors [137-139] recommended to look at the absolute values of Skewness and Kurtosis, the histogram, Q-Q Plots, or P-P plots to decide whether the data fall within normal or nonnormal distribution. In line with this suggestion, we carry out these tests and the outcomes demonstrate that the dispersion of the information is factually ordinary (see Table 5 and Figures 3 and 4). Therefore, we assume that the data are approximately following normal distribution [137-139].

\section{Results}

The following demographic data were extracted from the questionnaire: age, gender, educational level, number of bank employees, and type of bank.

Results from Table 6 depict that 257 respondents representing $73.4 \%$ were males, 93 respondents representing $26.6 \%$ were females; 56 of the respondents representing $16.0 \%$ were in the age range of " $18-25$ years", 245 respondents representing $70.0 \%$ were in the age range of "26-33 years", 44 respondents representing $12.6 \%$ were in the age range of "34-41 years", and 5 respondents representing $1.4 \%$ were above the age of 42 years. The results in Table 6 show that 3 of the respondents representing $0.9 \%$ are from the Basic level; 3 respondents representing 0.9\% are from the High school level, while 14 respondents representing $4.0 \%$ are from the diploma level; 57 of the
TABLE 3: Item loadings and reliability of constructs.

\begin{tabular}{lcccc}
\hline Items & FL & CA & CR & AVE \\
\hline IB1 & 0.760 & 0.907 & 0.917 & 0.650 \\
IB2 & 0.790 & & & \\
IB3 & 0.822 & & & \\
IB4 & 0.813 & & & \\
IB5 & 0.817 & & & \\
IB6 & 0.833 & & 0.902 & 0.698 \\
EI1 & 0.771 & 0.873 & & \\
EI2 & 0.860 & & & \\
EI3 & 0.839 & & 0.870 & \\
EI4 & 0.869 & & & \\
EP1 & 0.857 & 0.849 & & \\
EP2 & 0.809 & & & \\
EP3 & 0.828 & & & \\
\hline
\end{tabular}

EI: employee innovativeness, IB: Internet banking, EP: employee performance, FL: item loadings, CA: Cronbach's alpha, CR: composite reliability, and AVE: average variance extracted.

respondents representing $16.3 \%$ are from the undergraduate degree level, 258 of the respondents representing $73.7 \%$ are from the graduate level, and 15 of the respondents representing $4.2 \%$ are from other levels of education. The 157 respondents representing $44.9 \%$ are from banks with less than 100 employees; 114 respondents representing $32.6 \%$ are from a bank that has between 100 and 500 employees, 79 respondents representing 22.5\% are from a bank that has between 500 and 1000 employees. Lastly, the results in Table 1 show that 200 of the respondents representing $57.1 \%$ are from the public bank, while 150 of the respondents representing $42.9 \%$ are from the private bank.

4.1. Hypothesis Analysis. To carry out the structural equation model (path analysis), we employed a system of equation analysis using two-stage squares regression through the help of Stata (reg3 and estimate 2sls), as suggested in [129] that two-stage least squares regression is one of the powerful methods to test path analysis.

The test of the hypothesis was carried out on the effect of Internet banking on employee performance using the statistical tool Stata V.14. The results of the tested variables showed a significant and positive relationship with the predictor variables. Taking the first model, a test was carried out on the effect of Internet banking on employee performance, EP $(\beta=0.240$; $t=9.52, p<0.000$ ) with $R^{2}=0.2065$, which implies that IB does explain about $20.70 \%$ of the variation in EP.

We again tested the effect of Internet banking on employee innovativeness. IB $(\beta=0.219 ; t=5.09, p<0.000)$ with $R^{2}=0.069$ which means that IB explained $6.9 \%$ of variation in EI. The effect of employee innovativeness on employee performance was also tested, EI $(\beta=0.214 ; t=6.66$, $p<0.000)$. Thus, it led to the acceptance of hypotheses, $\mathrm{H} 1$, $\mathrm{H} 2$, and $\mathrm{H} 3$ (see Table 7 ).

Finally, the mediation effect of EI has also been considered. As reported in Table $8, \mathrm{IB} \rightarrow \mathrm{EI} \rightarrow \mathrm{EP} \quad(\beta=0.071, p<0.000$, $\mathrm{BC} 0.95 \mathrm{LL}=0.035$ and $\mathrm{UL}=0.116)$. Moreover, the indirect effects, as proposed by [140], have not amounted to a zero in 
TABLE 4: Interitem means (M), std. deviation, and correlation.

\begin{tabular}{|c|c|c|c|c|c|}
\hline & Mean $(\mathrm{M})$ & Std. deviation & IB & EI & EP \\
\hline IB & 21.531 & 4.974 & 1.000 & & \\
\hline EI & 13.426 & 4.127 & $0.263^{* *}$ & 1.000 & \\
\hline EP & 11.226 & 2.626 & $0.454^{* *}$ & $0.336^{* *}$ & 1.000 \\
\hline
\end{tabular}

$N=350 .{ }^{* *}$ Correlation is significant at the $p<0.01$ level (2-tailed).

TABLE 5: Tests of normality.

\begin{tabular}{|c|c|c|c|c|c|c|c|c|c|c|c|c|}
\hline & \multicolumn{3}{|c|}{ Kolmogorov-Smirnov ${ }^{a}$} & \multicolumn{3}{|c|}{ Shapiro-Wilk } & \multirow{2}{*}{ Skewness } & \multirow{2}{*}{$\begin{array}{l}\text { Std. error } \\
\text { of skewness }\end{array}$} & \multirow{2}{*}{$Z_{\text {skewness }}$} & \multirow{2}{*}{ Kurtosis } & \multirow{2}{*}{$\begin{array}{l}\text { Std. error } \\
\text { of kurtosis }\end{array}$} & \multirow{2}{*}{$Z_{\text {kurtosis }}$} \\
\hline & Statistic & $\mathrm{df}$ & Sig. & Statistic & $\mathrm{df}$ & Sig. & & & & & & \\
\hline EP & 0.182 & 350 & 0.000 & 0.938 & 350 & 0.000 & -0.693 & 0.130 & -5.33 & 0.231 & 0.260 & 0.89 \\
\hline EI & 0.137 & 350 & 0.000 & 0.945 & 350 & 0.000 & -0.601 & 0.130 & -4.62 & -0323 & 0.260 & -1.24 \\
\hline IB & 0.116 & 350 & 0.000 & 0.963 & 350 & 0.000 & -0.634 & 0.130 & -4.88 & 0.291 & 0.260 & 1.12 \\
\hline
\end{tabular}

${ }^{\mathrm{a}}$ Lilliefors significance correction.

between, which implied that there is mediation. Along these lines, it may be reasoned that a mediation effect has been statistically significant, showing that $\mathrm{H} 4$ was likewise accepted.

The results in Table 8 prove that both direct and indirect effects of Internet banking on the endogenous construct and employee performance (EP) are statistically and positively significant, indicating that employee innovativeness (EI) partially mediates the effect of IB (see Figure 5).

\section{Discussion and Conclusion}

The main aim of this paper was to determine the mediating role of employee innovativeness on the relationship between Internet banking and employee performance in some selected banks in the Republic of Congo. We have also looked at the relationship between Internet banking, employee innovativeness, and employee performance. To be able to achieve this objective, the theoretical model has been expanded, and empirically tested according to JD-R theory, Diffusion of Innovation (DOI) Theory, Absorptive Capacity Theory (ACT), and Resource-Based View Theory. In general, the results of this study showed that all hypotheses were accepted and are following expected directions.

In detail, the present investigation found that employee innovativeness exerts a significant and positive impact on employee performance. This finding is in line with the Resource-Based View Theory. Based on this theory, all organization resources are important for helping the company to achieve more excellent performance and gain competitive advantage, which, in turn, enhances overall profitability. Furthermore, the outcome of this research is consistent with some previous studies. For instance, [52] have found that employee innovativeness is vital for innovation technology and overall efficiency. The employees played a significant role as every bank's activity is immediately related to employees' attitude, motivation, and work culture. Thus, employee innovativeness is becoming a considerable determinant when measuring banks' overall efficiency and productivity. This point of view corresponds with [141]'s outcomes that human capital, relational capital, and structural capital are positively linked to quality and innovation speed, which ultimately ease a firm's operational and financial performance.

The finding of this study has confirmed the positive nexus among IB and EI. This finding is following JD-R Theory that posits that great job resources will lead to increased motivation, resulting in higher productivity. This outcome is also in line with previous empirical evidence that has found a significant positive relationship between IB and EI. For instance, [38] indicated that IT has contributed to high employee creativity and productivity in banks. This output is also in line with [7], in which it was found that IT results in more significant employee performance. Internet banking has a considerable effect on bank-related determinants, and individual-related elements of banks' employees in Delhi/NCR. They concluded that technology always plays a significant role in improving the performance and efficiency of banks' employees, which in turn increased their productivity.

The partial least square outcomes showed a significant and positive relationship between IB and EP. This finding is in line with [22], which showed that innovation efforts, innovation capabilities, and firm performance have a significant and robust relationship. Furthermore, the outcomes of this paper are consistent with some previous investigations that revealed the implementation of technology innovation by organizations affects the outcomes and leads to greater performance and competitive advantage $[25,36]$.

The results of this investigation show that employee innovativeness mediates the relationship between IB and EP. These outcomes are predictable with JD-R Theory that recommends that the activities of employees mediate the relationships between work environment assets and outputs (profitability). Especially, worker efficiency is upgraded with the presence of assets that can decrease their work hours, and finally, the satisfaction is changed into high profitability. This finding also reflects [7]'s point of view that innovation affects organization and employees by boosting employee satisfaction, reducing cost and clients wait-hours, increasing employee productivity, and finally enhancing bank performance. The possible explanations of this outcome are that the introduction of innovative 


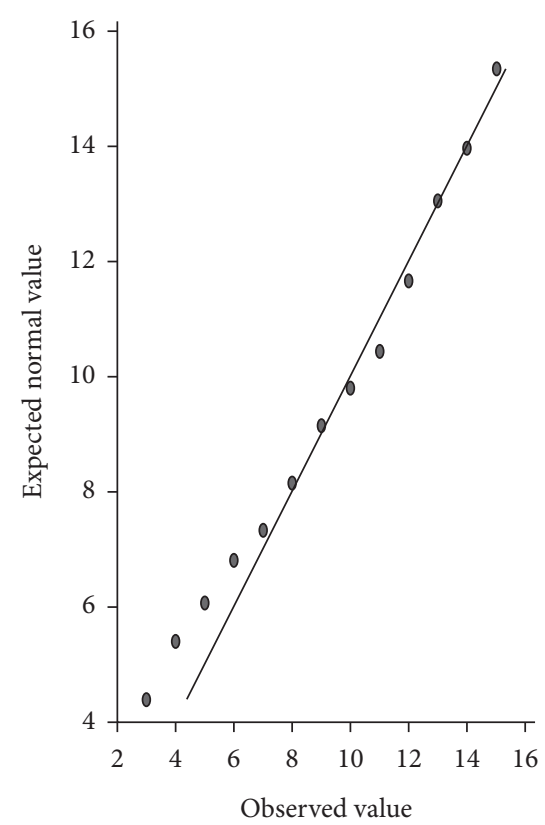

(a)

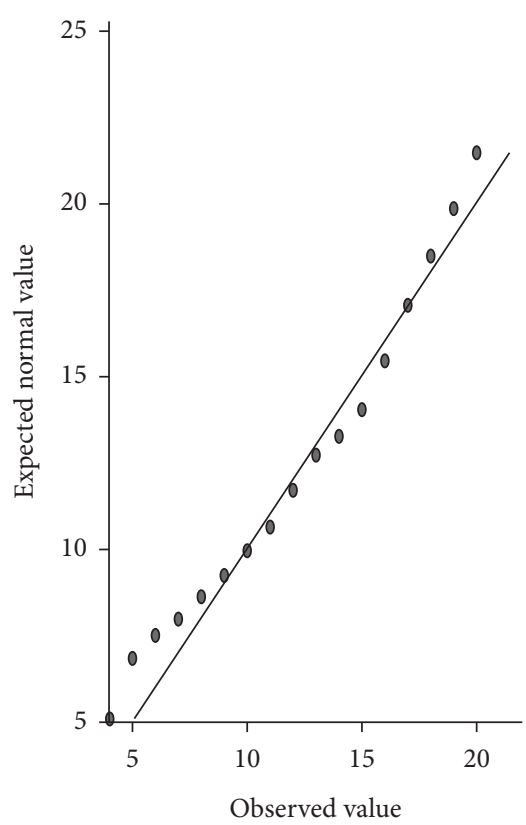

(b)

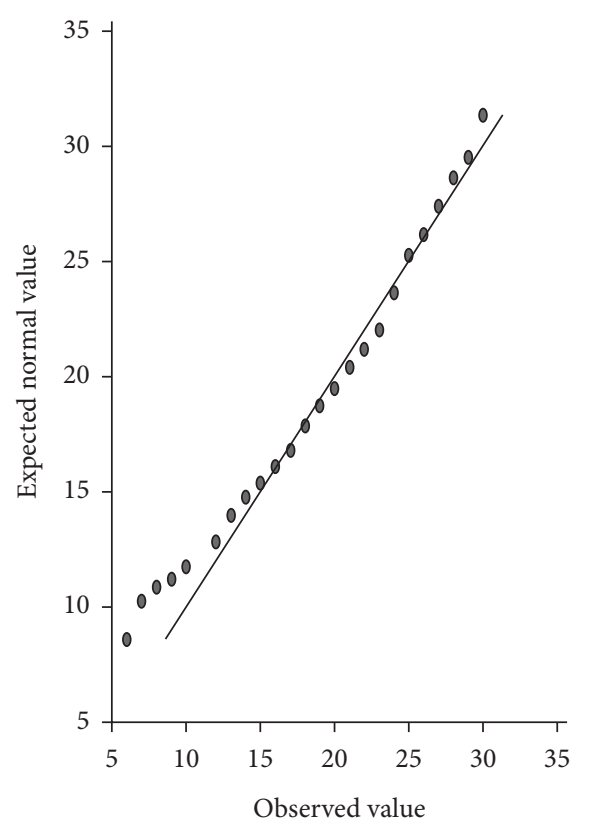

(c)

Figure 3: Normality test (Q-Q plots). (a) EP. (b) EI. (c) IB.

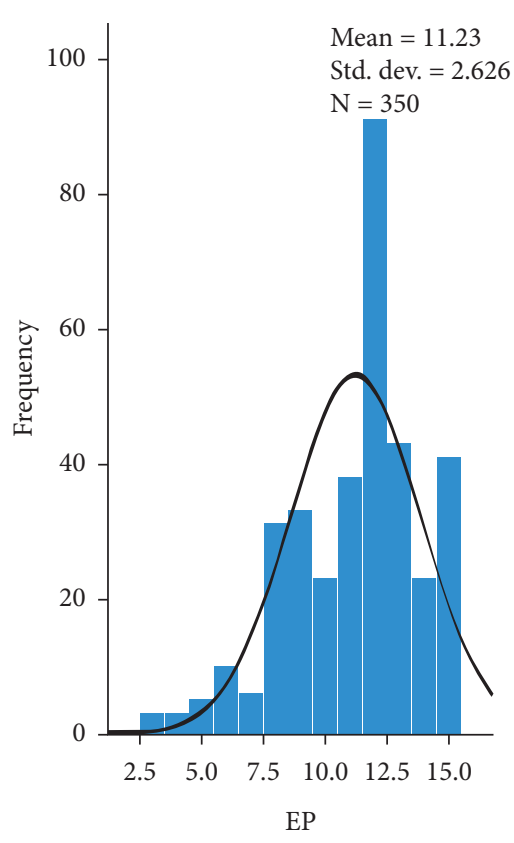

(a)

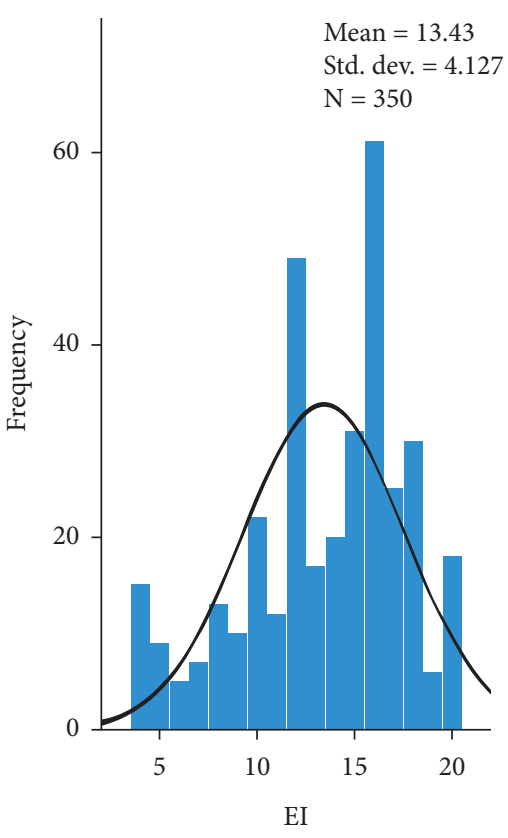

(b)

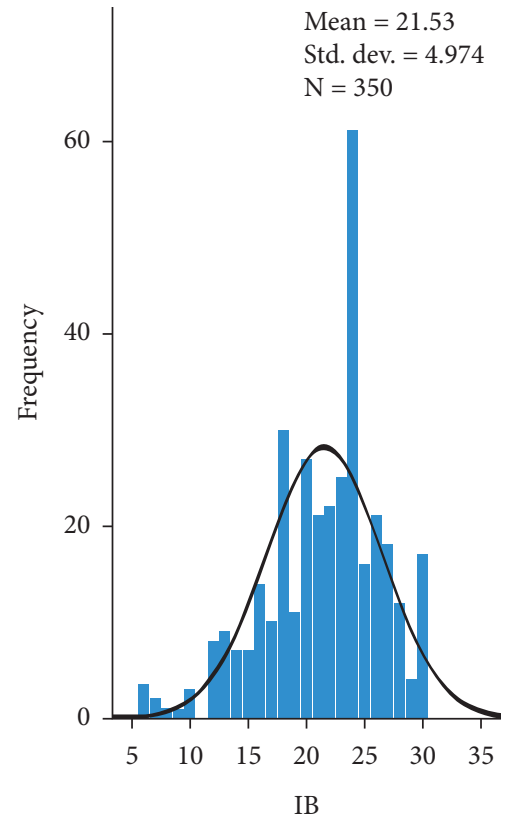

(c)

Figure 4: Normality test (histogram).

services like Internet banking services will make employees work innovatively and efficiently. This means that the bank managers must invest more in innovative technologies to make the work of the employees very easy so that they can have enough time for their customers. Furthermore, this research shows that IB is a crucial determinant of business improvement. In it, their workers are involved in workrelated activities for a few numbers of hours to ease their performance, enhance their satisfaction, and increase their productivity as a whole.

In conclusion, this research sought to understand the indicators of employee performance in which we mixed the J-DR model, Diffusion of Innovation (DOI) Theory, and Resource-Based View Theory. Divergence and convergence with past findings ascertained the expectation and confirmation that Internet banking and employee innovativeness 
TABLE 6: Demographics of participants.

\begin{tabular}{lcc}
\hline & \multicolumn{2}{c}{ Participants (no. =350) } \\
& Frequency & Percent \\
\hline Gender & 257 & 73.4 \\
Male & 93 & 26.6 \\
Female & 56 & \\
\hline Age & 245 & 16.0 \\
18-25 years & 44 & 70.0 \\
26-33 years & 5 & 12.6 \\
34-41 years & & 1.4 \\
42 and above & 3 & \\
Educational level & 3 & 0.9 \\
Basic level & 14 & 0.9 \\
High school & 57 & 4.0 \\
Diploma & 258 & 16.3 \\
Undergraduate & 15 & 73.7 \\
Graduate & & 4.2 \\
Others & 157 & 44.9 \\
\hline No. of employees & 114 & 32.6 \\
Less than 100 & 79 & 22.5 \\
100-500 & & 57.1 \\
500-1000 & 200 & 42.9 \\
\hline Type of bank & 150 & \\
Public & & Private
\end{tabular}

No. of participants $=350$.

TABle 7: Hypothesis test.

\begin{tabular}{lcccc}
\hline & $(1)$ & $(2)$ & $(3)$ & $(4)$ \\
& $\mathrm{EP}$ & $\mathrm{EI}$ & $\mathrm{EP}$ & $\mathrm{EP}$ \\
\hline \multirow{2}{*}{ IB } & $0.240^{* * *}$ & $0.219^{* * *}$ & & $0.208^{* * *}$ \\
& $(0.0252)$ & $(0.0429)$ & & $(0.0253)$ \\
EI & & & $0.214^{* * *}$ & $0.148^{* * *}$ \\
& & & $(0.0321)$ & $(0.0305)$ \\
Constant & $6.059^{* * *}$ & $8.719^{* * *}$ & $8.353^{* * *}$ & $4.768^{* * *}$ \\
$N$ & $(0.557)$ & $(0.948)$ & $(0.451)$ & $(0.602)$ \\
$R^{2}$ & 350 & 350 & 350 & 350 \\
RMSE & 0.207 & 0.069 & 0.113 & 0.257 \\
F-Stat & 2.343 & 3.987 & 2.477 & 2.270 \\
\hline
\end{tabular}

Standard errors in parentheses, ${ }^{*} p<0.05,{ }^{* *} p<0.01$, and ${ }^{* * *} p<0.001$; IB: Internet banking, EI: employee innovativeness, and EP: employee performance.

have significant and positive effects on employee performance. This investigation also asserts that employees (human capital) have to be considered as one of the most valuable factors in the survival of organizations. Thus, employee satisfaction and the degree of their happiness must be seriously given consideration. Also, employees must be provided a better salary, excellent health package, and better end of service benefit packages so that they will be motivated to innovate and complete their different tasks.

\section{Theoretical and Practical Implications}

From a theoretical perspective, this study contributes considerably to modern pieces of literature and information. In
TABLE 8: The mediation analysis (direct, indirect, and total effects).

\begin{tabular}{|c|c|c|c|c|c|}
\hline & Std. coef. & St. err. & $z$ & $P>z$ & $(95 \% \mathrm{CI})$ \\
\hline \multicolumn{6}{|l|}{ Direct effects } \\
\hline $\mathrm{EI} \longleftarrow \mathrm{IB}$ & 0.284 & 0.056 & 5.000 & 0.000 & $0.164-0383$ \\
\hline $\mathrm{EP} \longleftarrow \mathrm{EI}$ & 0.249 & .053 & 4.656 & 0.000 & 0.14 \\
\hline $\mathrm{EP} \longleftarrow \mathrm{IB}$ & 0.398 & 0.046 & 8.591 & 0.000 & $0.302-0.483$ \\
\hline Indirect effects & & & & & \\
\hline $\begin{array}{l}\mathrm{EP} \longleftarrow \text { IB } \\
\text { Total effects }\end{array}$ & 0.071 & 0.021 & 3.345 & 0.000 & $0.035-0.116$ \\
\hline $\mathrm{EI} \longleftarrow \mathrm{IB}$ & 0.279 & 0.056 & 5.000 & 0.000 & $0.164-0383$ \\
\hline $\mathrm{EP} \longleftarrow \mathrm{EI}$ & 0.249 & 0.053 & 4.656 & 0.000 & $0.145-0.353$ \\
\hline $\mathrm{EP} \longleftarrow \mathrm{IB}$ & 0.469 & 0.048 & 9.644 & 0.000 & $0.367-0.561$ \\
\hline
\end{tabular}

Note. The outputs from SmartPLS software.

the first place, this paper has tested the predominant recommendations that IB is unnecessary for workers and can diminish the profitability and innovative ideas of employees. Notably, this study has shown hypothetically and statistically that the utilization of IB can apply a beneficial outcome on workers' performance and, in the long run, increase their efficiency. Along these lines, IB ought not to be viewed as a negative factor in the working environment; instead, it is to be viewed as a superfluous determinant for employees to apply in their various tasks. Secondly, this is nearly the latest research that hypothesized the mediating variable of EI in a relationship between IB and EP. This assists in clarifying how a company can interpret IB and EI into high efficiency by raising workers' fulfillment. Third, according to the Resource-Based Theory, this investigation has combined aspects of the innovation technology in terms of IB, and aspect of the company's resource capabilities in terms of EI; we have employed those mentioned above together to estimate their mixed effects on job performance and productivity. Previous investigations have examined these factors separately. Therefore, mixing IB and EI in a single research has revealed a great understanding and an additional complete image of the backgrounds of workforce outputs. Fourthly, the majority of previous studies related to IB have been carried out in the Western context and obtained inconsistent findings. As corroborated in this research, the results of the survey in a non-Western or Asian context may differ from those from in developed nations. For instance, in this paper, IB and EI exert significant and positive effects on EP, which varies with some outcomes disclosed in the context of developed nations. Fifth, this research has productively mixed theories developed in the context of Western countries or Asia (e.g., JD-R model, Diffusion of Innovation Theory, Absorptive Capacity Theory, and Resource-Based View Theory) to explain and support conceptual framework which has been expounded in the context of non-Western countries, precisely the Republic of Congo. By doing so, this research gives another road to future investigations to additionally clarify and foresee the impact of IB and EI on other banks' variables through the usage of technology and innovation activities.

From a practical point of view, this study has theorized relations in another context and obtained a significant and positive link between the exogenous and endogenous 


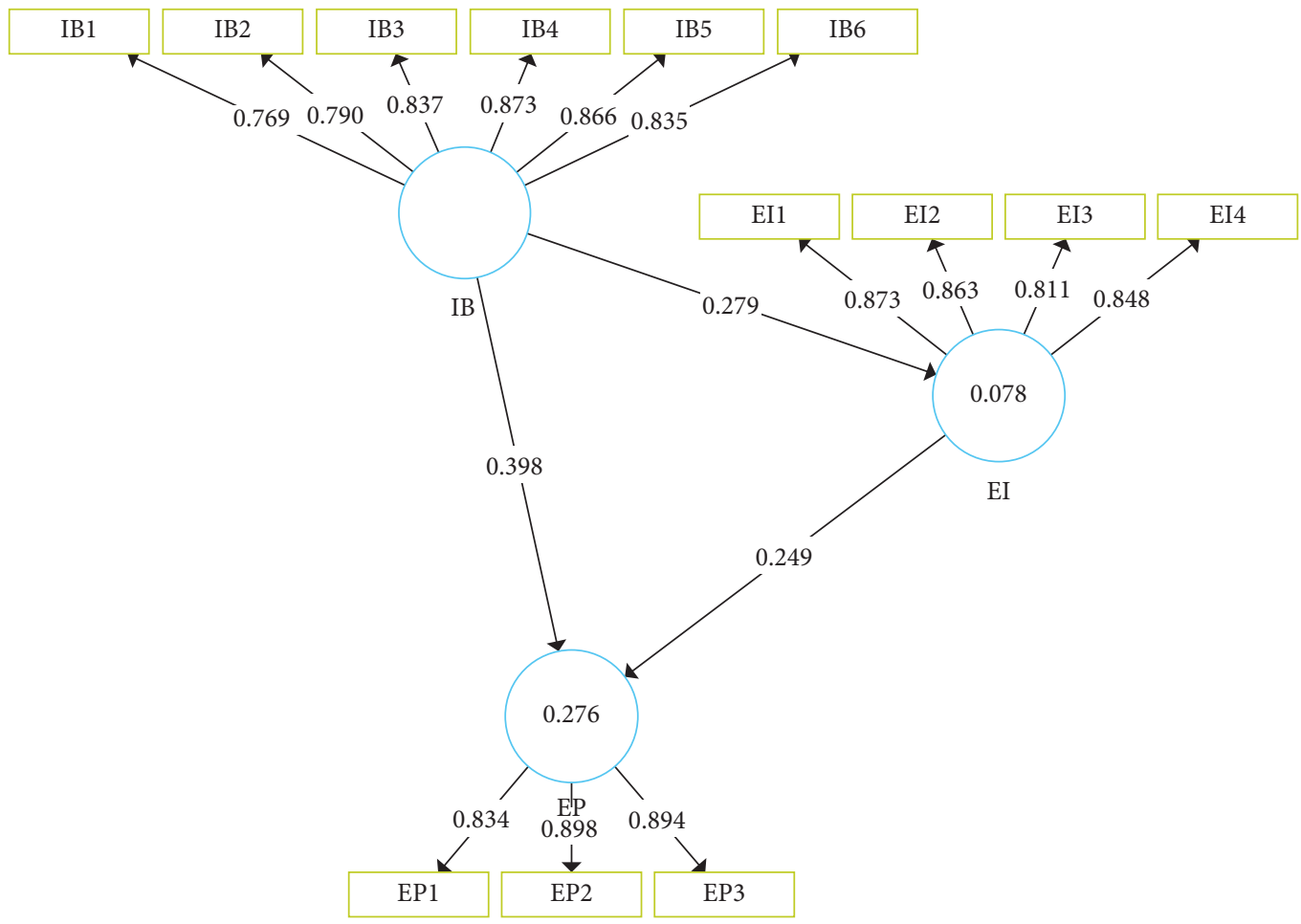

Figure 5: Structural equation modeling.

factors. This outcome has various implications for banks' management. Initially, bankers are encouraged to continually give and improve IT resources and promote the use of Internet by their employees. This can progress, propel their insight, accelerating the way toward achieving various undertakings, and fortify the joint effort and correspondence forms among workers. Also, the decision-makers inside these companies are encouraged to see IB as a decisive factor (IT investment that expands performance and makes the organization to gain a competitive advantage) instead of as a counterproductive indicator (IT speculation cost, which diminishes the organization's performance). Accordingly, they ought to allocate IT investment and improve their employees' work conditions to solve the company's workrelated matters, such as response to the clients' requests and operational issues related to the transactions or other problems. This may help employees decrease the clients' waiting hours and ease employees' efficiency in their different tasks.

At last, this is relied upon to expand their performance and productivity. Furthermore, political decision-makers inside the banks are encouraged to see IB as a factor in improving the employees' productivity rather than a determinant to influence employees' performance negatively. At long last, it ought to be noticed that management style is slowly transforming from a centralized to a decentralized method, where opportunity is given for how people play out their undertakings and how people are assessed on accomplishing the concurred performance factors. Thus, employees ought to be progressively crucial in these companies since it is a key factor of innovation technology and productivity, which will enhance EP.

\section{Limitations and Further Research Directions}

Even though this investigation has its merits, it also has a few limitations. Precisely, this research has depended on the samples taken from workers of financial business. Accordingly, the outcome from the present study cannot be summed up to the workers of different organizations. Future investigations may reconstruct this research by including various industries, for example, education, insurance, and healthcare, to upgrade the generalizability of the outcomes. Also, this investigation is cross-sectional, which brings up issues concerning causality. In this way, just discussions and conclusions of the general relationship between the factors of importance can be established. Future investigations can utilize lengthwise research to develop a clear image concerning the cause-impact relations among the factors of interests. This research has opened the road to future studies to analyze the precursors and outcomes of employees' innovativeness. Future investigations can look at the effect of Internet banking on an organization's human capital, incorporating employee satisfaction, customer satisfaction, competitive advantage, and intellectual capital. Besides, future investigations can look at the impact of technology innovation in the nation's financial development, in terms of innovation measurements such as Internet banking, organizations' digitalization, and e-business. Future studies are recommended to incorporate moderator variables such as Internet security, perceived risk, and employee job security. Another limit for this research is on the selection of sample size method, which was based on the formula proposed by [129]. This formula does not take into account the power of the test and the significance; therefore, future investigations 
must consider including $t$-test and significance in the determination of sample size. This current work contributes to the existing studies and knowledge on IB, and the scholars trust that future endeavors will continue and increase the knowledge progressively across the world about this area of study.

\section{Data Availability}

The datasets used and/or analyzed during the current study are available from the corresponding author on reasonable request.

\section{Conflicts of Interest}

The authors declare that there are no conflicts of interest.

\section{Acknowledgments}

This work was supported by the National Natural Science Foundation of China (Grant Nos. 71701082 and 71271103).

\section{References}

[1] T. Hu and C. Xie, "Competition, innovation, risk-taking, and profitability in the Chinese banking sector: an empirical analysis based on structural equation modeling," Discrete Dynamics in Nature and Society, vol. 2016, Article ID 3695379, 10 pages, 2016.

[2] R. I. Ibrahim and G. I. AlOmari, "The effect of talent management on innovation: evidence from Jordanian Banks," Management Science Letters, vol. 10, no. 6, pp. 1295-1306, 2020.

[3] S. Rahi and M. Abd Ghani, "The role of UTAUT, DOI, perceived technology security and game elements in internet banking adoption," World Journal of Science, Technology and Sustainable Development, vol. 15, no. 4, pp. 338-356, 2018.

[4] M. N. A. Siddik, G. Sun, S. Kabira, J. Shanmugan, and C. Yanjuan, "Impacts of E-banking on performance of banks in A developing economy: empirical evidence from Bangladesh," Journal of Business Economics and Management, vol. 17, no. 6, pp. 1066-1080, 2016.

[5] B. B.-H. Chai, P. S. Tan, and T. S. Goh, "Banking services that influence the bank performance," Procedia - Social and Behavioral Sciences, vol. 224, pp. 401-407, 2016.

[6] F. Campanella, M. R. Della Peruta, and M. Del Giudice, "The effects of technological innovation on the banking sector," Journal of the Knowledge Economy, vol. 8, no. 1, pp. 356-368, 2017.

[7] S. Gupta and A. Yadav, "The impact of electronic banking and information technology on the employees of banking sector," Management and Labour Studies, vol. 42, no. 4, pp. 379-387, 2017.

[8] F. Castellacci and V. Tveito, "Internet use and well-being: a survey and a theoretical framework," Research Policy, vol. 47, no. 1, pp. 308-325, 2018.

[9] K. Owusu Kwateng, E. E. Osei-Wusu, and K. Amanor, "Exploring the effect of online banking on bank performance using data envelopment analysis," Benchmarking: An International Journal, vol. 27, no. 1, pp. 137-165, 2019.

[10] H. Alhassany and F. Faisal, "Factors influencing the internet banking adoption decision in North Cyprus: an evidence from the partial least square approach of the structural equation modeling," Financial Innovation, vol. 4, no. 1, p. 29, 2018.

[11] J. Jayaram, A. Oke, and D. Prajogo, "The antecedents and consequences of product and process innovation strategy implementation in Australian manufacturing firms," International Journal of Production Research, vol. 52, no. 15, pp. 4424-4439, 2014.

[12] L. Ma, X. Zhai, W. Zhong, and Z.-X. Zhang, "Deploying human capital for innovation: a study of multi-country manufacturing firms," International Journal of Production Economics, vol. 208, pp. 241-253, 2019.

[13] B. B. M. Shao and W. T. Lin, "Assessing output performance of information technology service industries: productivity, innovation and catch-up," International Journal of Production Economics, vol. 172, pp. 43-53, 2016.

[14] A. Nazaritehrani and B. Mashali, "Development of E-banking channels and market share in developing countries," Financial Innovation, vol. 6, no. 1, p. 12, 2020.

[15] World Bank, "Congo-Gabon: toward regional digital integration,” 2020, https:/www.worldbank.org/en/news/ feature/2018/04/09/congo-gabon-toward-regional-digitalintegration.

[16] IMF, "Republic of Congo: selected issues, IMF country report No. 14/273," 2020, https://www.imf.org/external/pubs/ $\mathrm{ft} / \mathrm{scr} / 2014 / \mathrm{cr} 14273 . \mathrm{pdf}$.

[17] C. Chipeta and M. M. Muthinja, "Financial innovations and bank performance in Kenya: evidence from branchless banking models," South African Journal of Economic and Management Sciences, vol. 21, no. 1, pp. 1-11, 2018.

[18] A. Y. Obeng and P. L. Mkhize, "An exploratory analysis of employees and customers' responses in determining the technological innovativeness of banks," The Electronic Journal of Information Systems in Developing Countries, vol. 80, no. 1, pp. 1-23, 2017.

[19] C. Onay and E. Ozsoz, "The impact of internet-banking on brick and mortar branches: the case of Turkey," Journal of Financial Services Research, vol. 44, no. 2, pp. 187-204, 2013.

[20] N. J. Wainaina, "Mobile based loan management practices and financial performance of commercial banks in Kenya," Journal of Electronic Commerce Research, vol. 16, no. 7, pp. 3-7, 2017.

[21] H. Latan, C. J. Chiappetta Jabbour, A. B. Lopes de Sousa Jabbour, P. de Camargo Fiorini, and C. Foropon, "Innovative efforts of ISO 9001-certified manufacturing firms: evidence of links between determinants of innovation, continuous innovation and firm performance," International Journal of Production Economics, vol. 223, Article ID 107526, 2020.

[22] R. P. J. Rajapathirana and Y. Hui, "Relationship between innovation capability, innovation type, and firm performance," Journal of Innovation \& Knowledge, vol. 3, no. 1, pp. 44-55, 2018.

[23] A. Khorakian, H. Mohammadi Shahroodi, M. Jahangir, and Z. Nikkhah Farkhani, "Innovative work behavior in public organizations: the roles of ethical and knowledge sharing behaviors," Creativity Research Journal, vol. 31, no. 2, pp. 164-173, 2019.

[24] M. Lukes and U. Stephan, "Measuring employee innovation," International Journal of Entrepreneurial Behavior \& Research, vol. 23, no. 1, pp. 136-158, 2017.

[25] R. Shanker, R. Bhanugopan, B. I. J. M. van der Heijden, and M. Farrell, "Organizational climate for innovation and organizational performance: the mediating effect of innovative work behavior," Journal of Vocational Behavior, vol. 100, pp. 67-77, 2017. 
[26] J. Doran and G. Ryan, “The role of stimulating employees' creativity and idea generation in encouraging innovation behaviour in Irish firms," The Irish Journal of Management, vol. 36, no. 1, pp. 32-48, 2017.

[27] S. De Spiegelaere, M. Ramioul, and G. Van Gyes, "Good employees through good jobs," Employee Relations, vol. 39, no. 4, pp. 503-522, 2017.

[28] L. Alpkan, C. Bulut, G. Gunday, G. Ulusoy, and K. Kilic, "Organizational support for intrapreneurship and its interaction with human capital to enhance innovative performance," Management Decision, vol. 48, no. 5, pp. 732-755, 2010.

[29] C. B. Dobni, "The relationship between an innovation orientation and competitive strategy," International Journal of Innovation Management, vol. 14, no. 02, pp. 331-357, 2010.

[30] K. L. Unsworth and C. W. Clegg, "Why do employees undertake creative action?" Journal of Occupational and Organizational Psychology, vol. 83, no. 1, pp. 77-99, 2010.

[31] A. Engelen, L. Weinekötter, S. Saeed, and S. Enke, "The effect of corporate support programs on employees' innovative behavior: a cross-cultural study," Journal of Product Innovation Management, vol. 35, no. 2, pp. 230-253, 2018.

[32] W. L. Lin, N. Yip, J. A. Ho, and M. Sambasivan, "The adoption of technological innovations in a B2B context and its impact on firm performance: an ethical leadership perspective," Industrial Marketing Management, vol. 89, pp. 61-71, 2020.

[33] Y. Wei, H. Nan, and G. Wei, "The impact of employee welfare on innovation performance: evidence from China's manufacturing corporations," International Journal of Production Economics, vol. 228, p. 107753, 2020.

[34] J. C. F. de Guimarães, E. A. Severo, E. C. H. Dorion, F. Coallier, and P. M. Olea, "The use of organisational resources for product innovation and organisational performance: a survey of the Brazilian furniture industry," International Journal of Production Economics, vol. 180, pp. 135-147, 2016.

[35] I. Hashi and N. Stojčić, "The impact of innovation activities on firm performance using a multi-stage model: evidence from the Community Innovation Survey 4," Research Policy, vol. 42, no. 2, pp. 353-366, 2013.

[36] S. V. Scott, J. Van Reenen, and M. Zachariadis, "The longterm effect of digital innovation on bank performance: an empirical study of SWIFT adoption in financial services," Research Policy, vol. 46, no. 5, pp. 984-1004, 2017.

[37] M. Martínez-Domínguez and J. Mora-Rivera, "Internet adoption and usage patterns in rural Mexico," Technology in Society, vol. 60, Article ID 101226, 2020.

[38] A. Yaw Obeng and E. Boachie, "The impact of IT-technological innovation on the productivity of a bank's employee," Cogent Business \& Management, vol. 5, no. 1, 2018.

[39] J. Mohammad, F. Quoquab, S. Halimah, and R. Thurasamy, "Workplace internet leisure and employees' productivity," Internet Research, vol. 29, no. 4, pp. 725-748, 2019.

[40] T. D. Le and T. Ngo, "The determinants of bank profitability: a cross-country analysis," Central Bank Review, vol. 20, no. 2, pp. 65-73, 2020.

[41] P. Ji, X. Yan, and G. Yu, "The impact of information technology investment on enterprise financial performance in China," Chinese Management Studies, vol. 14, no. 3, pp. 529-542, 2019.

[42] S. K. Callaway, "Internet banking and performance," American Journal of Business, vol. 26, no. 1, pp. 12-25, 2011.
[43] İ. Akhisar, K. B. Tunay, and N. Tunay, "The effects of innovations on bank performance: the case of electronic banking services," Procedia-Social and Behavioral Sciences, vol. 195, pp. 369-375, 2015.

[44] S. Sathye and M. Sathye, "Do ATMs increase technical efficiency of banks in a developing country? Evidence from Indian banks," Australian Accounting Review, vol. 27, no. 1, pp. 101-111, 2017.

[45] L. M. Gutu, "The Impact of Internet Technology on the Romanian Banks Performance. 0702397," in Proceedings of the International Academic Conferences 0702397, International Institute of Social and Economic Sciences, Prague, Czech Republic, September 2014, https://ideas.repec.org/p/ sek/iacpro/0702397.html.

[46] T. Beck, T. Chen, C. Lin, and F. M. Song, "Financial innovation: the bright and the dark sides," Journal of Banking \& Finance, vol. 72, pp. 28-51, 2016.

[47] H. Do, P. S. Budhwar, and C. Patel, "Relationship between innovation-led HR policy, strategy, and firm performance: a serial mediation investigation," Human Resource Management, vol. 57, no. 5, pp. 1271-1284, 2018.

[48] P. T. Preenen, R. Vergeer, K. Kraan, and S. Dhondt, "Labour productivity and innovation performance: the importance of internal labour flexibility practices," Economic and Industrial Democracy, vol. 38, no. 2, pp. 271-293, 2017.

[49] C.-F. Cheng, M.-K. Lai, and W.-Y. Wu, "Exploring the impact of innovation strategy on R\&D employees' job satisfaction: a mathematical model and empirical research," Technovation, vol. 30, no. 7-8, pp. 459-470, 2010.

[50] H. A. Shih and E. Susanto, "Is innovative behavior really good for the firm?" International Journal of Conflict Management, vol. 22, no. 2, pp. 111-130, 2011.

[51] D. Liu, K. Jiang, C. E. Shalley, S. Keem, and J. Zhou, "Motivational mechanisms of employee creativity: a metaanalytic examination and theoretical extension of the creativity literature," Organizational Behavior and Human Decision Processes, vol. 137, pp. 236-263, 2016.

[52] Z. Husain, M. Dayan, and C. A. Di Benedetto, "The impact of networking on competitiveness via organizational learning, employee innovativeness, and innovation process: a mediation model," Journal of Engineering and Technology Management, vol. 40, pp. 15-28, 2016.

[53] J. Yan, D. E. Leidner, and H. Benbya, "Differential innovativeness outcomes of user and employee participation in an online user innovation community," Journal of Management Information Systems, vol. 35, no. 3, pp. 900-933, 2018.

[54] Y. F. Badir, B. Frank, and M. Bogers, "Employee-level open innovation in emerging markets: linking internal, external, and managerial resources," Journal of the Academy of Marketing Science, pp. 1-23, 2019.

[55] D. J. Hughes, A. Lee, A. W. Tian, A. Newman, and A. Legood, "Leadership, creativity, and innovation: a critical review and practical recommendations," The Leadership Quarterly, vol. 29, no. 5, pp. 549-569, 2018.

[56] N. V. Minh, Y. F. Badir, N. N. Quang, and B. Afsar, "The impact of leaders' technical competence on employees' innovation and learning," Journal of Engineering and Technology Management, vol. 44, pp. 44-57, 2017.

[57] S. Rahi and M. Abd Ghani, "Customer's perception of public relation in e-commerce and its impact on e-loyalty with brand image and switching cost," Journal of Internet Banking and Commerce, vol. 21, no. 3, 2016. 
[58] D. R. Compeau and C. A. Higgins, "Application of social cognitive theory to training for computer skills," Information Systems Research, vol. 6, no. 2, pp. 118-143, 1995.

[59] F. D. Davis, R. P. Bagozzi, and P. R. Warshaw, "Extrinsic and intrinsic motivation to use computers in the Workplacel," Journal of Applied Social Psychology, vol. 22, no. 14, pp. 1111-1132, 1992.

[60] E. M. Rogers, Diffusions of Innovation, Free Press of Glencoe, New York, NY, USA, 1st edition, 1962.

[61] S. Taylor and P. Todd, "Decomposition and crossover effects in the theory of planned behavior: a study of consumer adoption intentions," International Journal of Research in Marketing, vol. 12, no. 2, pp. 137-155, 1995.

[62] R. L. Thompson, C. A. Higgins, and J. M. Howell, "Personal computing: toward a conceptual model of utilization," MIS Quarterly, vol. 15, no. 1, p. 125, 1991.

[63] J. Barney, "Firm resources and sustained competitive advantage," Journal of Management, vol. 17, no. 1, pp. 99-120, 1991.

[64] P. Joyce and G. Winch, "A framework for codifying business models and process models in e-Business design," in Value Creation from E-Business Models, pp. 35-64, Elsevier, Amsterdam, Netherlands, 2004.

[65] C. K. Prahalad and G. Hamel, "Strategy as a field of study: why search for a new paradigm?" Strategic Management Journal, vol. 15, no. S2, pp. 5-16, 1994.

[66] J.-C. Spender and R. M. Grant, "Knowledge and the firm: overview," Strategic Management Journal, vol. 17, no. S2, pp. 5-9, 1996.

[67] B. Wernerfelt, "A resource-based view of the firm," Strategic Management Journal, vol. 5, no. 2, pp. 171-180, 1984.

[68] R. M. Grant, "The resource-based theory of competitive advantage: implications for strategy formulation," California Management Review, vol. 33, no. 3, pp. 114-135, 1991.

[69] Nevo and Wade, "The formation and value of IT-enabled resources: antecedents and consequences of synergistic relationships," MIS Quarterly, vol. 34, no. 1, p. 163, 2010.

[70] J. B. Barney, Gaining and Sustaining Competitive Advantage, Pearson Higher Ed, London, UK, 2014.

[71] Y. S. Cho and K. Linderman, "Resource-based product and process innovation model: theory development and empirical validation," Sustainability, vol. 12, no. 3, p. 913, 2020.

[72] J. B. Barney and A. M. Arikan, The Blackwell Handbook of Strategic Management, M. A. Hitt, R. E. Freeman, and J. S. Harrison, Eds., vol. 5, Hoboken, NJ, USA, Blackwell Publishing Ltd, 2005.

[73] M. A. Peteraf, "The cornerstones of competitive advantage: a resource-based view," Strategic Management Journal, vol. 14, no. 3, pp. 179-191, 1993.

[74] S. Gagnon, "Resource-based competition and the new operations strategy," International Journal of Operations \& Production Management, vol. 19, no. 2, pp. 125-138, 1999.

[75] S. K. Gouda and H. Saranga, "Sustainable supply chains for supply chain sustainability: impact of sustainability efforts on supply chain risk," International Journal of Production Research, vol. 56, no. 17, pp. 5820-5835, 2018.

[76] R. Hayes, "Operations, strategy, and technology: pursuing the competitive edge," Strategic Direction, vol. 22, no. 7, 2006.

[77] W. M. Cohen and D. A. Levinthal, "Innovation and learning: the two faces of R \& D," The Economic Journal, vol. 99, no. 397, p. 569, 1989.
[78] W. M. Cohen and D. A. Levinthal, "Absorptive capacity: a new perspective on learning and innovation," Administrative Science Quarterly, vol. 35, no. 1, p. 128, 1990.

[79] W. M. Cohen and D. A. Levinthal, "Fortune favors the prepared firm," Management Science, vol. 40, no. 2, pp. 227-251, 1994.

[80] T. M. Amabile, "A model of creativity and innovation in organizations," Research in Organizational Behavior, vol. 10, no. 1, pp. 123-167, 1988.

[81] E. Dane, "Reconsidering the trade-off between expertise and flexibility: a cognitive entrenchment perspective," Academy of Management Review, vol. 35, no. 4, pp. 579-603, 2010.

[82] S. T. Fiske and S. E. Taylor, Social Cognition: From Brains to Culture, Sage, Thousand Oaks, CA, USA, 2nd edition, 2013.

[83] H. W. Volberda, N. J. Foss, and M. A. Lyles, "PERSPECTIVE-absorbing the concept of absorptive capacity: how to realize its potential in the organization field," Organization Science, vol. 21, no. 4, pp. 931-951, 2010.

[84] G. Dosi, "Technological paradigms and technological trajectories," Research Policy, vol. 11, no. 3, pp. 147-162, 1982.

[85] D. Mowery and N. Rosenberg, "The influence of market demand upon innovation: a critical review of some recent empirical studies," Research Policy, vol. 8, no. 2, pp. 102-153, 1979.

[86] P. J. Lane, B. R. Koka, and S. Pathak, "The reification of absorptive capacity: a critical review and rejuvenation of the construct," Academy of Management Review, vol. 31, no. 4, pp. 833-863, 2006.

[87] A. Spithoven, B. Clarysse, and M. Knockaert, "Building absorptive capacity to organise inbound open innovation in traditional industries," Technovation, vol. 30, no. 2, pp. 130-141, 2010.

[88] D. Jiménez-Castillo and M. Sánchez-Pérez, "Nurturing employee market knowledge absorptive capacity through unified internal communication and integrated information technology," Information \& Management, vol. 50, no. 2-3, pp. 76-86, 2013.

[89] L. Dahlander, S. O’Mahony, and D. M. Gann, "One foot in, one foot out: how does individuals' external search breadth affect innovation outcomes?," Strategic Management Journal, vol. 37, no. 2, pp. 280-302, 2016.

[90] Q. Li, P. G. Maggitti, K. G. Smith, P. E. Tesluk, and R. Katila, "Top management attention to innovation: the role of search selection and intensity in new product introductions," Academy of Management Journal, vol. 56, no. 3, pp. 893-916, 2013.

[91] H. A. Simon, "Bounded rationality and organizational learning," Organization Science, vol. 2, no. 1, pp. 125-134, 1991.

[92] T. G. Schweisfurth and C. Raasch, “Absorptive capacity for need knowledge: antecedents and effects for employee innovativeness," Research Policy, vol. 47, no. 4, pp. 687-699, 2018.

[93] G. Todorova and B. Durisin, "Absorptive capacity: valuing a reconceptualization," Academy of Management Review, vol. 32, no. 3, pp. 774-786, 2007.

[94] J. J. Jansen, F. A. Van Den Bosch, and H. W. Volberda, "Managing potential and realized absorptive capacity: how do organizational antecedents matter?" Academy of Management Journal, vol. 48, no. 6, pp. 999-1015, 2005.

[95] A. L. J. Ter Wal, P. Criscuolo, and A. Salter, "Making a marriage of materials: the role of gatekeepers and shepherds in the absorption of external knowledge and innovation 
performance," Research Policy, vol. 46, no. 5, pp. 1039-1054, 2017.

[96] X. Deng, W. J. Doll, and M. Cao, "Exploring the absorptive capacity to innovation/productivity link for individual engineers engaged in IT enabled work," Information \& Management, vol. 45, no. 2, pp. 75-87, 2008.

[97] M. Tortoriello, "The social underpinnings of absorptive capacity: the moderating effects of structural holes on innovation generation based on external knowledge," Strategic Management Journal, vol. 36, no. 4, pp. 586-597, 2015.

[98] B. Ryan and N. C. Gross, "The diffusion of hybrid seed corn in two Iowa communities," Rural Sociology, vol. 8, no. 1, p. $15,1943$.

[99] E. M. Rogers, Diffusion of Innovations. Revised, Simon \& Schuster, New York, NY, USA, 5th edition, 2003.

[100] M. Y. Yi, J. D. Jackson, J. S. Park, and J. C. Probst, "Understanding information technology acceptance by individual professionals: toward an integrative view," Information \& Management, vol. 43, no. 3, pp. 350-363, 2006.

[101] J. Zhao and P. O. de Pablos, "Regional knowledge management: the perspective of management theory," Behaviour \& Information Technology, vol. 30, no. 1, pp. 39-49, 2011.

[102] T. Oliveira, M. Thomas, G. Baptista, and F. Campos, "Mobile payment: understanding the determinants of customer adoption and intention to recommend the technology," Computers in Human Behavior, vol. 61, pp. 404-414, 2016.

[103] M. Demirbag, E. Tatoglu, M. Tekinkus, and S. Zaim, “An analysis of the relationship between TQM implementation and organizational performance," Journal of Manufacturing Technology Management, vol. 17, no. 6, pp. 829-847, 2006.

[104] G. M. Abdalkrim, "The impact of strategic planning activities on private sector organizations performance in Sudan: an empirical research," International Journal of Business and Management, vol. 8, no. 10, p. p134, 2013.

[105] S. E. Hatane, "Employee satisfaction and performance as intervening variables of learning organization on financial performance," Procedia - Social and Behavioral Sciences, vol. 211, pp. 619-628, 2015.

[106] V. Korenková, J. Závadský, and M. Lis, "Linking a performance management system and competencies: qualitative research," Engineering Management in Production and Services, vol. 11, no. 1, pp. 51-67, 2019.

[107] S. Zhuwao, H. Ngirande, W. Ndlovu, and S. T. Setati, "Gender diversity, ethnic diversity and employee performance in a South African higher education institution," SA Journal of Human Resource Management, vol. 17, 2019.

[108] E. Sadikoglu and C. Zehir, "Investigating the effects of innovation and employee performance on the relationship between total quality management practices and firm performance: an empirical study of Turkish firms," International Journal of Production Economics, vol. 127, no. 1, pp. 13-26, 2010.

[109] R. M. Walker, F. Damanpour, and C. A. Devece, "Management innovation and organizational performance: the mediating effect of performance management," Journal of Public Administration Research and Theory, vol. 21, no. 2, pp. 367-386, 2011.

[110] S. Choi, H. Jang, and J. Hyun, "Correlation between innovation and performance of construction firms," Canadian Journal of Civil Engineering, vol. 36, no. 11, pp. 1722-1731, 2009.
[111] S. Osman, S. H. Shariff, and M. N. A. Lajin, "Does innovation contribute to employee performance?” Procedia - Social and Behavioral Sciences, vol. 219, pp. 571-579, 2016.

[112] S. Nambisan, R. Agarwal, and M. Tanniru, "Organizational mechanisms for enhancing user innovation in information technology," MIS Quarterly, vol. 23, no. 3, p. 365, 1999.

[113] G. Torkzadeh and W. J. Doll, "The development of a tool for measuring the perceived impact of information technology on work," Omega, vol. 27, no. 3, pp. 327-339, 1999.

[114] S. Melián-González and J. Bulchand-Gidumal, "Information technology and front office employees' performance," International Journal of Contemporary Hospitality Management, vol. 29, no. 8, pp. 2159-2177, 2017.

[115] F. Castellacci, M. Gulbrandsen, J. Hildrum, I. Martinkenaite, and E. Simensen, "Functional centrality and innovation intensity: employee-level analysis of the Telenor group," Research Policy, vol. 47, no. 9, pp. 1674-1687, 2018.

[116] N. K. Jaiswal and R. L. Dhar, "Transformational leadership, innovation climate, creative self-efficacy and employee creativity: a multilevel study," International Journal of Hospitality Management, vol. 51, pp. 30-41, 2015.

[117] R. Bysted, "Innovative employee behaviour," European Journal of Innovation Management, vol. 16, no. 3, pp. 268284, 2013.

[118] M. Saunila, "Innovation capability for SME success: perspectives of financial and operational performance," Journal of Advances in Management Research, vol. 11, no. 2, pp. 163-175, 2014.

[119] O. Sinaga, M. Lis, and M. S. A. Razimi, "Education and core skills in the performance with mediating role of employee innovation," Polish Journal of Management Studies, vol. 19, no. 2, pp. 363-373, 2019.

[120] T. J. Grosser, D. Obstfeld, E. W. Choi et al., "A sociopolitical perspective on employee innovativeness and job performance: the role of political skill and network structure," Organization Science, vol. 29, no. 4, pp. 612-632, 2018.

[121] Y. Zhang, J. Zhang, J. Forest, and C. Chen, “The negative and positive aspects of employees' innovative behavior: role of goals of employees and supervisors," Frontiers in Psychology, vol. 9, p. 1871, 2018.

[122] S. Park and S. J. Jo, "The impact of proactivity, leadermember exchange, and climate for innovation on innovative behavior in the Korean government sector," Leadership \& Organization Development Journal, vol. 39, no. 1, pp. 130149, 2018.

[123] T. Akram, S. Lei, M. J. Haider, and S. T. Hussain, "The impact of organizational justice on employee innovative work behavior: mediating role of knowledge sharing," Journal of Innovation \& Knowledge, vol. 5, no. 2, pp. 117-129, 2019.

[124] W. B. Schaufeli, "Applying the job demands-resources model," Organizational Dynamics, vol. 46, no. 2, pp. 120-132, 2017.

[125] B. Kör, I. Wakkee, and P. van der Sijde, "How to promote managers' innovative behavior at work: individual factors and perceptions," Technovation, vol. 99, Article ID 102127, 2020.

[126] K. Y. Koay, "Workplace ostracism and cyberloafing: a moderated-mediation model," Internet Research, vol. 28, no. 4, pp. 1122-1141, 2018.

[127] A. Martín-Oliver and V. Salas-Fumás, “The output and profit contribution of information technology and advertising investments in banks," Journal of Financial Intermediation, vol. 17, no. 2, pp. 229-255, 2008. 
[128] J. C. Westland, "Lower bounds on sample size in structural equation modeling," Electronic Commerce Research and Applications, vol. 9, no. 6, pp. 476-487, 2010.

[129] J. C. Westland, Structural Equation Models:From Paths to Networks, Springer International Publishing, vol. 22, New York, NY, USA, 2015.

[130] K. Al-Qeisi, C. Dennis, E. Alamanos, and C. Jayawardhena, "Website design quality and usage behavior: unified theory of acceptance and use of technology," Journal of Business Research, vol. 67, no. 11, pp. 2282-2290, 2014.

[131] J. Hammoud, R. M. Bizri, and I. El Baba, "The impact of E-banking service quality on customer satisfaction: evidence from the Lebanese banking sector," SAGE Open, vol. 8, no. 3, 2018.

[132] S. Rahi, M. Abd.Ghani, and A. Hafaz Ngah, "Integration of unified theory of acceptance and use of technology in internet banking adoption setting: evidence from Pakistan," Technology in Society, vol. 58, p. 101120, 2019.

[133] Y.-L. Wu, Y.-H. Tao, and P.-C. Yang, "Learning from the past and present: measuring Internet banking service quality," The Service Industries Journal, vol. 32, no. 3, pp. 477-497, 2012.

[134] J. Henseler, C. M. Ringle, and M. Sarstedt, “A new criterion for assessing discriminant validity in variance-based structural equation modeling," Journal of the Academy of Marketing Science, vol. 43, no. 1, pp. 115-135, 2015.

[135] C. M. Voorhees, M. K. Brady, R. Calantone, and E. Ramirez, "Discriminant validity testing in marketing: an analysis, causes for concern, and proposed remedies," Journal of the Academy of Marketing Science, vol. 44, no. 1, pp. 119-134, 2016.

[136] P. B. Lowry and J. Gaskin, "Partial least squares (PLS) structural equation modeling (SEM) for building and testing behavioral causal theory: when to choose it and how to use it," IEEE Transactions on Professional Communication, vol. 57, no. 2, pp. 123-146, 2014.

[137] H.-Y. Kim, "Statistical notes for clinical researchers: assessing normal distribution (2) using skewness and kurtosis," Restorative Dentistry \& Endodontics, vol. 38, no. 1, p. 52, 2013.

[138] P. Mishra, C. Pandey, U. Singh, A. Gupta, C. Sahu, and A. Keshri, "Descriptive statistics and normality tests for statistical data," Annals of Cardiac Anaesthesia, vol. 22, no. 1, pp. 67-72, 2019.

[139] J. Uttley, "Power analysis, sample size, and assessment of statistical assumptions-improving the evidential value of lighting research," LEUKOS, vol. 15, no. 2-3, pp. 143-162, 2019.

[140] K. J. Preacher and A. F. Hayes, "Asymptotic and resampling strategies for assessing and comparing indirect effects in multiple mediator models," Behavior Research Methods, vol. 40, no. 3, pp. 879-891, 2008.

[141] Z. Wang, S. Cai, H. Liang, N. Wang, and E. Xiang, "Intellectual capital and firm performance: the mediating role of innovation speed and quality," The International Journal of Human Resource Management, vol. 32, no. 6, pp. 1222-1250, 2018. 